\title{
Sedimentary and atmospheric sources of iron around South Georgia, Southern Ocean: a modelling perspective
}

\author{
I. Borrione ${ }^{1}$, O. Aumont ${ }^{2}$, M. C. Nielsdóttir ${ }^{3, *}$, and R. Schlitzer ${ }^{1}$ \\ ${ }^{1}$ Alfred Wegener Institute Helmholtz Centre for Polar and Marine Research, Columbusstrasse, 27568 Bremerhaven, Germany \\ ${ }^{2}$ Laboratoire de Physique des Océans Institut Européen de la Mer, 29280 Plouzané, France \\ ${ }^{3}$ University of Southampton, National Oceanography Centre, European Way, SO14 3ZH, Southampton, UK \\ *now at: Old Dominion University, Department of Ocean, Earth and Atmospheric Sciences, 4600 Elkhorn Avenue, Norfolk \\ VA 23529, USA
}

Correspondence to: I. Borrione (ines.borrione@gmail.com)

Received: 23 May 2013 - Published in Biogeosciences Discuss.: 2 July 2013

Revised: 12 February 2014 - Accepted: 14 February 2014 - Published: 9 April 2014

\begin{abstract}
In high-nutrient low-chlorophyll waters of the western Atlantic sector of the Southern Ocean, an intense phytoplankton bloom is observed annually north of South Georgia. Multiple sources, including shallow sediments and atmospheric dust deposition, are thought to introduce iron to the region. However, the relative importance of each source is still unclear, owing in part to the scarcity of dissolved iron $(\mathrm{dFe})$ measurements in the South Georgia region. In this study, we combine results from a recently published dFe data set around South Georgia with a coupled regional hydrodynamic and biogeochemical model to further investigate iron supply around the island. The biogeochemical component of the model includes an iron cycle, where sediments and dust deposition are the sources of iron to the ocean. The model captures the characteristic flow patterns around South Georgia, hence simulating a large phytoplankton bloom to the north (i.e. downstream) of the island. Modelled dFe concentrations agree well with observations (mean difference and root mean square errors of $\sim 0.02 \mathrm{nM}$ and $\sim 0.81 \mathrm{nM}$ ) and form a large plume to the north of the island that extends eastwards for more than $800 \mathrm{~km}$. In agreement with observations, highest $\mathrm{dFe}$ concentrations are located along the coast and decrease with distance from the island. Sensitivity tests indicate that most of the iron measured in the main bloom area originates from the coast and very shallow shelf-sediments (depths $<20 \mathrm{~m}$ ). Dust deposition exerts almost no effect on surface chlorophyll $a$ concentrations. Other sources of iron such as run-off and glacial melt are not represented explicitly in the model, however we discuss their role in the local iron budget.
\end{abstract}

\section{Introduction}

The island of South Georgia is located in the western Atlantic sector of the Southern Ocean at the northeastern limit of the Scotia Sea. It lies along the North Scotia Ridge (Figs. 1 and 2 for topographic features in the region), and is situated between two of the main fronts of the easterly flowing Antarctic Circumpolar Current (ACC): the Polar Front (PF) and the Southern ACC Front (SACCF). The PF crosses the North Scotia Ridge at Shag Rocks Passage and then flows eastwards, always remaining due north of the island. The SACCF reaches South Georgia from the southwest, it flows around the southern shelf of the island and then veers anticyclonically towards the Georgia Basin before resuming its eastwards course (Orsi et al., 1995; Thorpe et al., 2002).

The ACC, PF and SACCF control the physical and chemical properties of the oceanic waters surrounding South Georgia. In particular, there is a strong transition from high to low silicate waters across the PF (Brzezinski et al., 2001 and Campanelli et al., 2011). At the beginning of the growth season nitrate and silicate range from 20-30 nM, whereas phosphate concentrations are close to $1.3-2$ nM (CARS 2009; Ridgway et al., 2002); hence concentrations of all macronutrients are well above the requirements for phytoplankton growth. In the vicinity of South Georgia, local processes such as run-off, glacial melt as well as solar heating and water mass retention, can lead to shelf-water temperature and salinity properties that may be very different from those observed in the oceanic ACC waters (Whitehouse et al., 1996; Korb and Whitehouse., 2004; Young et al., 2011; Meredith et al., 2005; Brandon et al., 1999). 


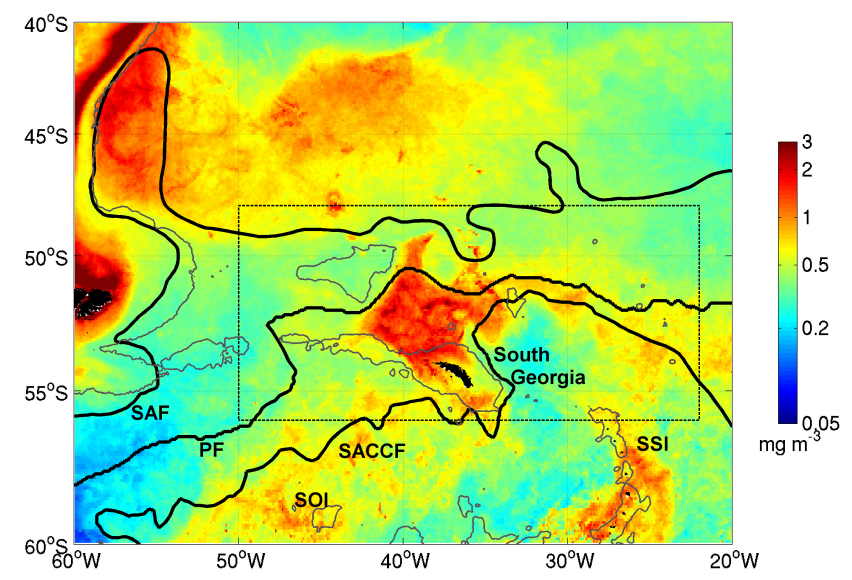

Fig. 1. Austral summer (January-February) chlorophyll $a$ climatology derived from MODIS for the 2003-2012 time period in the southwestern sector of the Atlantic Southern Ocean. Bold lines indicate the Subantarctic Front (SAF, Orsi et al., 1995), the Polar Front (PF, Moore et al., 1999) and the Southern ACC Front (SACCF, Thorpe et al., 2002). The position of the South Orkney Islands (SOI) and the South Sandwich Islands (SSI) are also indicated. The rectangle indicates the South Georgia area referred to in the text.

Satellite ocean colour imagery shows a large $\left(\sim 145000 \mathrm{~km}^{2}\right.$, Borrione and Schlitzer, 2013) and longlived phytoplankton bloom ( $>4$ months) that occurs to the north and northwest of South Georgia. Chlorophyll $a(\mathrm{Chl} a)$ concentrations often exceed $10 \mathrm{mg} \mathrm{m}^{-3}$ (Korb et al., 2004), leading to one of the strongest seasonal atmospheric- $\mathrm{CO}_{2}$ sinks in the open Southern Ocean (Jones et al., 2012). These high levels of phytoplankton biomass are in sharp contrast with the surrounding high-nutrient low-chlorophyll (HNLC) waters where, despite the presence of similarly high macronutrient concentrations, phytoplankton blooms of similar magnitude have not been observed (Fig. 1).

The spatial and temporal dynamics of the South Georgia bloom are still being investigated; ongoing research has indicated that a continuous supply of iron from the island's shelf is most likely one of the most important drivers (Nielsdóttir et al., 2012). The currents flowing along and over the wide $(30-100 \mathrm{~km})$ continental shelf of the island could pick-up iron from shelf sediments and would then transport the ironenriched waters towards the Georgia Basin, where intense blooms are regularly found (Nielsdóttir et al., 2012; Korb et al., 2008; Borrione and Schlitzer, 2013). Other sources of iron other than the coastal region are possible, although they have not yet been ascertained from in situ observations: for example, run-off and glacial-melt (see Gerringa et al., 2012; Raiswell et al., 2008) as well as upwelling at the shelf edge (Whitehouse et al., 2008a) or the deposition of dust from remote regions (i.e. the Patagonian Desert; Meskhidze et al., 2007; Johnson et al., 2010) or from local sources, as observed previously in the Kerguelen region (Blain et al., 2008; Heimburger et al., 2012).

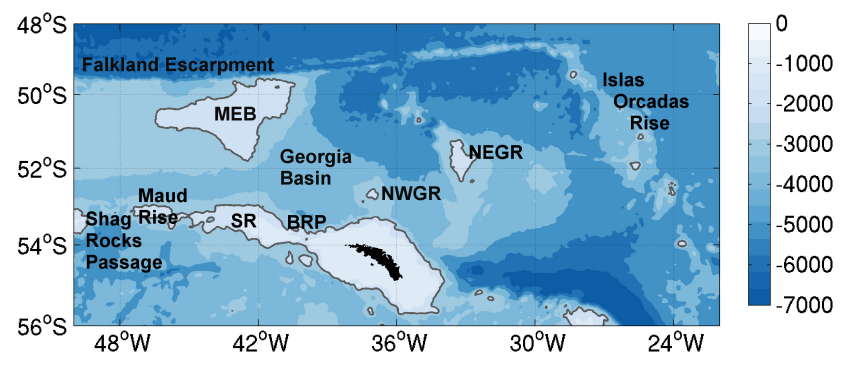

Fig. 2. Bathymetry and main topographic features in the South Georgia area: MEB: Maurice Ewing Bank; SR: Shag Rocks; BRP: Black Rocks Passage; NWGR: North West Georgia Rise; NEGR: Northeast Georgia Rise. Bathymetric contours for the $2000 \mathrm{~m}$ are indicated with thin lines.

In this study we address the importance of sedimentary and atmospheric iron sources around South Georgia. A hydrodynamic regional model (ROMS - Regional Oceanic Modelling System; Shchepetkin and McWilliams, 2005) was coupled with a biogeochemical model that includes a sedimentary iron source (PISCES - Pelagic Integration Scheme for Carbon and Ecosystem Studies; Aumont and Bopp, 2006). Previous biogeochemical models addressing iron limitation have focussed on dust deposition as the iron source (i.e. Parekh et al., 2004; Aumont et al., 2003). However, more recent studies have highlighted the importance of sedimentary sources for constraining global and regional iron budgets (Elrod et al., 2004; Moore and Braucher, 2008). Previous biogeochemical models of iron limitation have mostly focussed on the Southern Ocean as a whole (e.g. Tagliabue et al., 2009; Moore and Braucher, 2008), and here we present the first attempt to construct a regional biogeochemical model that constrains multiple iron sources in the South Georgia region.

After introducing the modelling tools and observational data sets, we evaluate the model's performance in the South Georgia area and in particular the model's ability to simulate surface dissolved iron ( $\mathrm{dFe}$ ) concentrations. Finally, we present results from sensitivity runs performed to identify the relative importance of the two iron sources considered here, and the distribution-pathways of $\mathrm{dFe}$ concentrations in the region. The results provide an opportunity to investigate natural iron fertilization around and downstream of South Georgia to compensate the current lack of adequate in situ dFe measurements.

\section{Model description}

\subsection{The hydrodynamic model ROMS}

The hydrodynamic model used for this study is the version of ROMS (Shchepetkin and McWilliams, 2005) which makes use of the Adaptive Grid Refinement in Fortran (AGRIF) procedure, (i.e. ROMS_AGRIF; Debreu and Blayo, 2008; Penven et al., 2006). 
ROMS_AGRIF is a three-dimensional, split-explicit, freesurface, primitive equation model. The model's grid combines horizontal orthogonal curvilinear coordinates, and vertical coordinates that are discretized in terrain-following curvilinear coordinates (i.e. sigma-layers) using high-order numerical methods. ROMS_AGRIF is based on the Boussinesq approximation and hydrostatic vertical momentum balance and solves the free surface primitive equations in an earth-centred rotating environment. The model's code (version V1.1) and the pre- and post-processing routines (Penven et al., 2008) used in this study, together with the biogeochemical model PISCES described below, were obtained from the web page of the Institut de Recherche pour le Développement (http://www.romsagrif.org/). To date, ROMS_AGRIF has been utilized by several regional oceanographic studies (e.g. Karakas et al., 2006; Penven et al., 2006), but not in the Southern Ocean.

\subsection{The biogeochemical model PISCES}

PISCES (Aumont and Bopp, 2006) is a 24-compartment biogeochemical model. It simulates the biogeochemical cycles of oxygen, carbon and the main micro- and macronutrients controlling phytoplankton growth, i.e. iron, phosphate, nitrate, ammonia and silicate. The phytoplankton compartment is comprised of nanophytoplankton and diatoms, with only diatoms requiring silicate for growth. Moreover, PISCES includes a grazer compartment (i.e. micro- and mesozooplankton) as well as a non-living detritus compartment, consisting of small and big organic particles, sized at $0-100 \mu \mathrm{m}$ and $100 \mu \mathrm{m}-5 \mathrm{~mm}$. In all living compartments the total carbon biomass is calculated explicitly and C/N/P ratios are assumed constant and close to Redfield values of 122/16/1. Additionally, for the phytoplankton compartment, PISCES explicitly calculates concentrations of chlorophyll (Chl), iron and silicate (diatoms only). Consequently, the internal ratios for $\mathrm{Fe} / \mathrm{C}, \mathrm{Chl} / \mathrm{C}$, and $\mathrm{Si} / \mathrm{C}$ are allowed to vary. Conversely, these ratios are kept constant in the zooplankton compartment; the bacterial compartment is not modelled explicitly.

The inclusion of an iron cycle (briefly described below and schematically represented in Fig. 3) is a key aspect of PISCES development to perform biogeochemical modelling in the iron-limited Southern Ocean. In the model, iron is supplied to the ocean in dissolved form from both atmospheric dust-deposition and sediment mobilization (Aumont and Bopp, 2006). Aeolian deposition of iron on the ocean is estimated from the climatological monthly maps of dust deposition modelled by Tegen and Fung (1995), which is similar to recent studies (Ginoux et al., 2001; Mahowald et al., 2005; Li et al., 2008) and only includes South America, Africa and Australia as sources of dust to the Southern Ocean. No information is available for the emission and deposition of dust originating directly from South Georgia. The annual dust deposition estimated by Tegen and Fung (1995) around South Georgia is $1-5 \mathrm{~g} \mathrm{~m}^{-2} \mathrm{yr}^{-1}$ and is com-

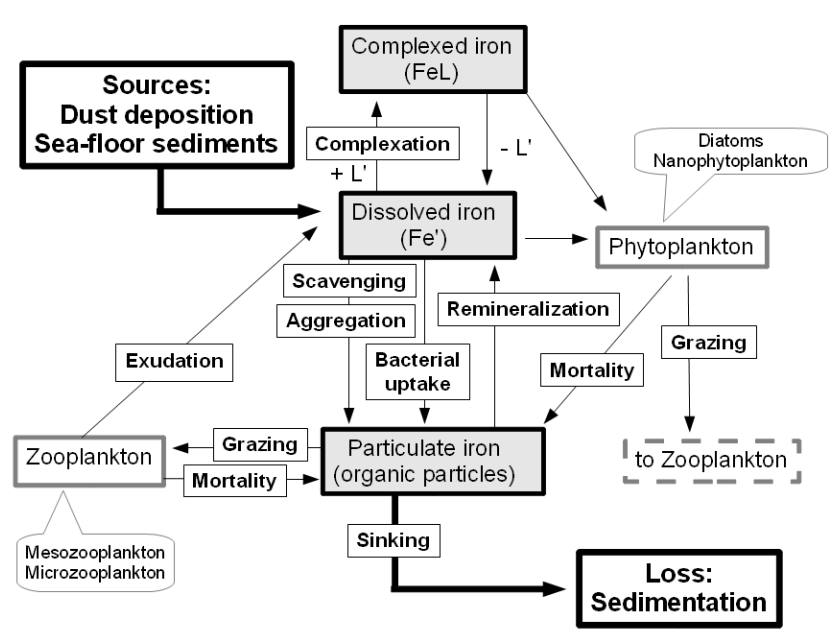

Fig. 3. Schematics of the iron cycle in PISCES as implemented in the current application (modified from Slemons et al., 2009). Fe' indicates free inorganic $\mathrm{dFe}, \mathrm{L}$ ' are ligands, while $\mathrm{FeL}$ indicates $\mathrm{dFe}$ complexed to ligands.

parable to the results of more recent modelling experiments (Mahowald et al., 2005; Ginoux et al., 2001). In PISCES iron content and solubility in dust particles are constant and set at $3.5 \%$, and $2 \%$ respectively. The iron content of dust particles adopted in PISCES appears to be consistent with modelling estimates of Patagonian dust deposition to the Atlantic Southern Ocean (Johnson et al., 2010). Solubility of iron in dust is not well constrained and several ranges have been proposed (i.e. Baker and Croot, 2010; Mahowald et al., 2005). In this study we adopted a solubility value equal to the one proposed by Jickells and Spokes (2001) and that is in agreement with numerous modelling studies (Moore and Braucher, 2008; Parekh et al., 2004, Johnson et al., 2010). Once in the water column, dust particles sink at $5 \mathrm{~m}_{\text {day }}{ }^{-1}$ and undergo constant dissolution until they reach the seafloor and are lost to the sediments (Aumont and Bopp, 2006).

The flux of sedimentary iron from the model's sea-floor topography, constructed as explained in Sect. 2.3 below, is variable in order to approximate the effect of oxygen levels in the sediments. Following the work of Aumont and Bopp (2006), the maximum flux is set to $1 \mu \mathrm{mol} \mathrm{dFe} \mathrm{m}^{-2} \mathrm{day}^{-1}$, which minimized the root mean square between their model results and the global data sets. Since anoxic sediments (i.e. those one would find in the presence of abundant organic matter) are likely to release more iron to seawater (Elrod et al., 2004), the maximum flux of $\mathrm{dFe}$ from sediments is modulated using the relative contribution of anaerobic processes (i.e. denitrification) to total mineralization of organic matter in the sediments. Adopting a simplified version of the meta-model of Middelburg et al. (1996), the depth of each sediment grid cell gives an indirect indication of how well the sediments are oxygenated and is thus used as a proxy for the importance of anaerobic processes in organic 
matter mineralization. Middelburg et al., 1996 and Aumont and Bopp, 2006 provide further details on this approximation, which is applied equally to all grid points located along the model's bathymetry. A similar representation of variable sedimentary sources of iron, with a maximum iron flux of $2 \mu \mathrm{mol} \mathrm{dFe} \mathrm{m}{ }^{-2}$ day $^{-1}$, was used by Moore and Braucher (2008) to improve the agreement of their biogeochemical modelling results with an extensive dFe global data set including the Southern Ocean.

Once in the water column, $\mathrm{dFe}$ in free inorganic form ( $\mathrm{Fe}$ ' in Fig. 3) can undergo complexation with one type of ligand ( ${ }^{\prime}$ ' in Fig. 3) or be scavenged onto particles. To the best of our knowledge, there is no information regarding the concentration and type of ligands in the South Georgia area, therefore, ligand concentration in the model was set to $0.6 \mathrm{nM}$, a value derived from the study of Johnson et al (1997) and commonly used in biogeochemical models (Parekh et al., 2004). Scavenging of dFe onto particles depends on the total load of organic particles and, together with aggregation, leads to the formation of particulate organic iron. Particulate organic iron is either reintroduced into the $\mathrm{dFe}$ pool through remineralization, or it is lost to the sediments via particle sinking.

Previous biogeochemical model simulations using PISCES have demonstrated its capability to adequately reproduce global $\mathrm{dFe}$ and pigment biomass distributions, proving it to be an appropriate tool for a variety of studies concerning ocean biogeochemistry, including those in the Southern Ocean (Aumont and Bopp, 2006; Slemons et al., 2009; Tagliabue et al., 2008, 2009).

\subsection{Model configuration, boundary conditions and forcing fields}

In the present configuration, the coupled ROMS_AGRIFPISCES model was implemented over the ocean domain depicted in Fig. 1, defined between $\left(60-20^{\circ} \mathrm{W}\right)$ and $\left(60-40^{\circ} \mathrm{S}\right)$ with a resolution of approximately $11 \mathrm{~km}$. The size of the domain was chosen in order to maintain sufficient distance between South Georgia and the domain-boundaries, thus limiting the effects of the four open-boundary conditions on the solutions (see also Young et al., 2011). At the average latitude and longitude of the model-domain, the Rossby radius is $\sim 15 \mathrm{~km}$ (Chelton et al., 1998), indicating that the current resolution is eddy permitting. Along the vertical dimension we used 32 sigma-coordinate layers. As it was important to assess the model's ability to reproduce $\mathrm{dFe}$ concentrations, but also chlorophyll patterns in the region, the sigma-coordinate layers were stretched to increase vertical resolution at the surface (few metres). The r-parameter measuring the slope of the sigma-layers (Beckmann and Haidvogel, 1993) was kept to the default value of 0.25 proposed for the preparation of the model's grid. Experiments initially performed to test the effect of changing r-parameter values (ranging 0.2-0.25) on our simulations yielded comparable results.
The ROMS pre-processing toolbox (Penven et al., 2008) is used to construct the model's bathymetry using ETOPO2 (Smith and Sandwell, 1997). According to the chosen spatial resolution (here $\sim 11 \mathrm{~km}$ ) the ETOPO2 bathymetry is smoothed to prevent horizontal pressure gradient errors, while coastlines are constructed with land-sea masking that is generated from the unfiltered topography (Penven et al., 2008). However, as the smoothing procedure may generate incongruities between the resulting smoothed topography and the coastline (i.e. grid points without water), around coastlines the minimum ocean depth is predefined to $50 \mathrm{~m}$. Consequently, the model bathymetry of the South Georgia region is vertical around the coastline and it deepens progressively only at depths greater than $50 \mathrm{~m}$. Sedimentary sources of iron (see Sect. 2.2 above) are equally calculated from all grid points located along the model's bathymetry. With a resolution of $11 \mathrm{~km}$, the resulting model bathymetry conserves the main topographic characteristics of the region (compare panels in Fig. 4), but does not resolve smaller-scale features like fjords and canyons or the complex island's coastline (Fretwell et al., 2009).

All forcing and boundary conditions used in the simulations derive from monthly climatologies. In some cases, the climatologies were constructed specifically for the purposes of this study averaging several years of available data, while in other cases, the climatologies were included in the ROMSTOOLS pre-processing toolbox (Penven et al., 2008). Water temperature, salinity, sea level and velocity fields used at the boundaries and for the model's initial conditions derive from the Simple Ocean Data Assimilation reanalysis (SODA, Carton and Giese, 2008). SODA variables were retrieved from the web (http://iridl.ldeo.columbia.edu/) for the years 1998-2008 and elaborated with the ROMSTOOLS pre-processing toolbox (Penven et al., 2008). Climatologies for fresh water and heat fluxes derive from the Comprehensive Ocean-Atmosphere Data Set (COADS, Da Silva et al., 1994), while the climatology for surface wind stress is obtained from QuikSCAT measurements for the 20002007 time period (Quick scatterometer, http://www.ifremer. fr/opendap/cerdap1/cersat/wind/14/quikscat/daily/). Sea surface temperatures from Pathfinder satellite observations (Casey and Cornillon, 1999) were utilized to restore modelled surface temperatures. The latter three data sets, i.e. COADS, QuikSCAT and Pathfinder, were included in the ROMSTOOLS pre-processing toolbox.

Boundary and initial conditions for $\mathrm{dFe}$, nitrate, phosphate, silicate and oxygen were derived from the World Ocean Atlas 2005 climatological data sets (Conkright et al, 2002) included in the ROMSTOOLS pre-processing toolbox, while the boundary and initial conditions for Chl $a$, phytoplankton and zooplankton biomass were obtained from existing ORCA2 model simulations (Aumont and Bopp, 2006), and successively adapted to the current domain size, grid structure and resolution. In the reference simulation, 
hereafter called SEDDUST, boundary conditions and surface forcings are equivalent to those described above.

\subsection{Model simulations and sensitivity tests}

Model spin-up was carried out for 20 years until quasiequilibrium was reached, and then for 10 additional years to verify the reproducibility of our results. All model results shown in the following are extracted from the last modelling year.

In addition to the reference SEDDUST simulation, we performed several different sensitivity runs (Table 1) in which we modified the iron sources present in the last three modelling years (i.e. the 28th, 29th and 30th yr of simulation). As our study mostly focuses on processes occurring in the surface layer of the ocean, three modelling years were sufficient to allow for a qualitative understanding of the relative importance of the two iron sources considered in this study, and for providing an indication of the water depth of the sediments contributing most of the $\mathrm{dFe}$ observed at the surface.

In two sensitivity runs either sedimentary or aeolian sources of iron were removed from the system (simulations are named NOSED_DUST and SED_NODUST, respectively). In every other sensitivity run, atmospheric sources of iron were kept identical to those utilized in the SEDDUST scenario, whereas the reductive mobilization of iron was limited to sediments present at selected $5 \mathrm{~m}$-thick ocean depth intervals, which at depths shallower than $50 \mathrm{~m}$ occupied comparable sediment surface areas. Six simulations resolved the top 0-30 m surface layer, while in two additional runs reductive mobilization of iron was limited to the sediments present at the 50-55 m and 100-105 m ocean depth intervals only. Deeper sediments were not considered because, as described in Sect. 4.5 below, simulations with $\mathrm{dFe}$ sources at depths greater than $50 \mathrm{~m}$ did not significantly change results obtained considering shallower depth bands.

\section{Observational data set}

\subsection{Ocean colour measurements}

Aqua MODIS (Moderate Resolution Imaging Spectroradiometer) Standard Mapped Images - Level 3 products, for the ocean-colour monthly composites of January and February from the 2003-2012 time period processed by the Goddard Space Flight Center and projected on a regular spatial grid of $9 \mathrm{~km}$, were retrieved from the Distributed Active Archive Center (http://oceancolor.gsfc.nasa.gov/). The full data set was used to construct the climatology depicted in Fig. 1, while the averages obtained from the monthly composites of January and February 2008, corresponding to the sampling period of in situ surface $\mathrm{dFe}$ concentrations (Nielsdóttir et al., 2012, see below) were used for comparisons with model outputs (Fig. 6). Moreover, as the model showed a tendency to underestimate surface $\mathrm{Chl} a$ concentrations ob- served in 2008 (Sect. 4.3 and Fig. 6), we verified this behaviour with a comparison of model results with Chl $a$ concentration averages from January and February 2011, which we identified as one of the least productive austral summers amongst all years of ocean colour observations in the Distributed Active Archive Center from 1998 to 2012. Ocean colour estimates depicted in Fig. $6 \mathrm{a}$ and $\mathrm{b}$ were interpolated onto the model's coarser grid resolution $(\sim 11 \mathrm{~km})$.

\subsection{Surface water circulation}

Surface circulation patterns in the South Georgia area (region outlined with a rectangle in Fig. 1) were estimated from Aviso satellite altimetry (http://www.aviso.oceanobs. com/duacs/). The Aviso altimeter product is based on multiple altimeter missions (Jason-1 and 2, T/P, Envisat, GFO, ERS-1 and 2 and Geosat) and provides a consistent and homogeneous data set. Weekly delayed-time values for the zonal and meridional components of surface current velocity computed from absolute topography, re-sampled on a regular $0.25^{\circ}$ grid, were extracted for January and February of 2008 for comparisons with modelled surface $(0-30 \mathrm{~m})$ velocities (Fig. 4), but also for January and February of 2011 (Fig. 6b). Closer to the coast where satellite altimetry suffers from inaccuracies and data gaps (Bouffard et al., 2007; Volkov et al., 2007), the validation of modelled surface circulation patterns was integrated using in situ current measurements or surface drifter trajectories presented in previous publications (Whitehouse et al., 2008a; Thorpe et al., 2002; Korb et al., 2008; Meredith et al., 2003).

\subsection{Macronutrients}

Surface $(0-30 \mathrm{~m})$ monthly climatologies of nitrate, phosphate and silicate concentrations, distributed by the CSIRO Atlas of Regional Seas (CARS; http://www.marine.csiro.au/ $\sim$ dunn/cars2009/; Ridgway et al., 2002) and available at a uniform $0.5^{\circ}$ grid resolution, were retrieved and then averaged over the area centred around the main South Georgia bloom region $\left(45-32^{\circ} \mathrm{W} ; 56-50^{\circ} \mathrm{S}\right.$ in Fig. 7a). Concentration averages and their standard deviation (SD), which provides an indication of the macronutrient spatial variability over the chosen area, were compared with monthly averages from the last modelling year (Fig. 5). Another indication of variance is given by the one standard error interval (SE), calculated by dividing the SD by the square root of the total number of values present in the chosen area.

\subsection{In situ dFe measurements}

For the validation of modelled $\mathrm{dFe}$ concentrations, we used in situ measurements around South Georgia that were obtained during two oceanographic cruises to the Scotia Sea aboard the RRS James Clark Ross, as part of the British Antarctic Survey Discovery 2010 FOODWEBS programme. Underway surface $\mathrm{dFe}$ concentrations are from the period 
Table 1. Averages of surface $\mathrm{dFe}$ and $\mathrm{Chl} a$ concentrations from each sensitivity run and from the domain around South Georgia depicted in Fig. 7a. rms and mean differences between each sensitivity run and the SEDDUST scenario are also indicated.

\begin{tabular}{|c|c|c|c|c|}
\hline Name of scenario & $\begin{array}{l}\text { Average } \pm \text { std } \\
\left(\mathrm{nM} 10^{-1} \mathrm{dFe}\right)\end{array}$ & $\begin{array}{c}\text { Average } \pm \text { std } \\
\left(\mathrm{mgChl} a \mathrm{~m}^{-3}\right)\end{array}$ & $\begin{array}{l}\text { rms/mean diff. } \\
\text { (nM dFe) }\end{array}$ & $\begin{array}{l}\text { rms/mean diff. } \\
\left(\mathrm{mg} \mathrm{Chl} a \mathrm{~m}^{-3}\right)\end{array}$ \\
\hline SEDDUST $^{\mathrm{a}}$ & $1.98 \pm 6.01$ & $0.33 \pm 0.28$ & I & I \\
\hline SED_NODUST & $1.92 \pm 5.90$ & $0.31 \pm 0.29$ & $0.01 /-0.01$ & $0.02 /-0.02$ \\
\hline NOSED_DUST ${ }^{\mathrm{a}}$ & $0.25 \pm 0.05$ & $0.15 \pm 0.02$ & $0.62 /-0.18$ & $0.33 /-0.18$ \\
\hline SEDDUST_0-5 m ${ }^{\mathrm{a}}$ & $0.82 \pm 2.32$ & $0.25 \pm 0.22$ & $0.39 /-0.12$ & $0.14 /-0.09$ \\
\hline SEDDUST_5-10 $\mathrm{m}^{\mathrm{a}}$ & $0.42 \pm 0.84$ & $0.2 \pm 0.14$ & $0.54 /-0.15$ & $0.23 /-0.14$ \\
\hline SEDDUST_10-15 m & $0.35 \pm 0.51$ & $0.18 \pm 0.1$ & $0.57 /-0.16$ & $0.26 /-0.15$ \\
\hline SEDDUST_15-20 $\mathrm{m}^{\mathrm{a}}$ & $0.32 \pm 0.38$ & $0.17 \pm 0.08$ & $0.58 /-0.17$ & $0.28 /-1.58$ \\
\hline SEDDUST_20-25 m & $0.30 \pm 0.31$ & $0.17 \pm 0.07$ & $0.59 /-0.17$ & $0.29 /-0.16$ \\
\hline SEDDUST_25-30m & $0.3 \pm 0.28$ & $0.17 \pm 0.06$ & $0.6 /-0.17$ & $0.3 /-0.16$ \\
\hline SEDDUST_50-55 m & $0.26 \pm 0.10$ & $0.16 \pm 0.03$ & $0.61 /-0.17$ & $0.32 /-0.17$ \\
\hline SEDDUST_100-105 m ${ }^{\mathrm{a}}$ & $0.25 \pm 0.05$ & $0.15 \pm 0.03$ & $0.62 /-0.17$ & $0.33 /-0.18$ \\
\hline SEDDUST_100-105 m b & $0.25 \pm 0.05$ & $0.15 \pm 0.03$ & $0.001 / \sim 0$ & $0.002 / 0.001$ \\
\hline
\end{tabular}

${ }^{\text {a }}$ Surface $(0-30 \mathrm{~m})$ averages of $\mathrm{dFe}$ and $\mathrm{Chl} a$ for these simulations are shown in Fig. 10.

$\mathrm{b}$ rms and mean differences are calculated with respect to the NOSED_DUST simulation.

between 23 January and 10 February of 2008 (see Fig. 2c of Nielsdóttir et al. (2012) and Fig. 7a of the present manuscript for the sampling locations and measured values), while $\mathrm{dFe}$ depth profiles $(0-1000 \mathrm{~m})$ are for the period $18-25$ November 2006 and from the region to the north (i.e. downstream, around $52.86^{\circ} \mathrm{S} 40.10^{\circ} \mathrm{W}$ ) and south (i.e. upstream, around $55.21^{\circ} \mathrm{S} 41.24^{\circ} \mathrm{W}$ ) of South Georgia. Therefore, due to differences in times of sampling, for the purposes of the validation, we used modelling results from January-February (Fig. 7) and November (Fig. 8) of the last modelling year to maintain a seasonal correspondence between observed and modelled dFe concentrations.

\section{Results}

In the following section we compare modelled physical and biogeochemical properties with available observational data to assess the ability of the model to reproduce environmental conditions around South Georgia. In all cases we use model results from the last modelling year. As boundary conditions and forcing fields are derived from monthly climatologies repeated cyclically in each simulation year, the modelled fields cannot reproduce the interannual variability observed from in situ or remote-sensing data. The model results are used to describe the potential distribution and transport pathways of surface $\mathrm{dFe}$ concentrations around South Georgia, as well as the relative importance of sedimentary and aeolian sources of iron in the region.

\subsection{Circulation patterns around South Georgia}

Surface circulation patterns estimated from Aviso satellite altimetry during January and February of 2008 and those obtained from model simulations (i.e. January-February of the last modelling year) are compared in Fig. 4 to evaluate the ability of the model to reproduce the main features of circulation around South Georgia. Satellite altimetry (Fig. 4a) indicates that the ACC and its fronts enter the South Georgia area from the southwest and cross the North Scotia Ridge at three locations (see also Venables et al., 2012; Korb et al., 2004): the PF flows through Shag Rocks Passage $\left(\sim 48^{\circ} \mathrm{W}\right.$, $53^{\circ} \mathrm{S}$ ), while the SACCF continues eastwards around the southern flank of South Georgia and then crosses the North Scotia Ridge to the east of the island following closely the $2000 \mathrm{~m}$ bathymetry contour. Satellite altimetry also indicates a northward flow through Black Rock Passage, a narrow but deep trough located between Shag Rocks and South Georgia $\left(\sim 40^{\circ} \mathrm{W}, 54^{\circ} \mathrm{S}\right)$. The presence of the latter flow was evidenced previously with in situ current measurements and surface drifter trajectories (Whitehouse et al., 2008a; Korb et al., 2008). To the north of South Georgia, an intense current (> $20 \mathrm{~cm} \mathrm{~s}^{-1}$, Whitehouse et al., 2008a) flows westward around the island's shelf break and subsequently veers north and then east following the western and northern margins of the Georgia Basin. The resulting current field describes a cyclonic flow around the Georgia Basin, as clearly depicted by Korb et al., 2008 and by Meredith et al., 2003 using surface drifter trajectories in the region. Over the Georgia Basin, the circulation is characterized by intense currents along its margins $\left(\sim 20-25 \mathrm{~cm} \mathrm{~s}^{-1}\right)$, and by weaker currents over its central area (often below $10-15 \mathrm{~cm} \mathrm{~s}^{-1}$ ). Similar velocity gradients were indicated by modelling results presented by Thorpe et al., 2002. Once the flow exits the Georgia Basin it continues east along a convoluted route close to NEGR and the Islas Orcadas Rise (refer to Fig. 2 for topographic features in the region). 


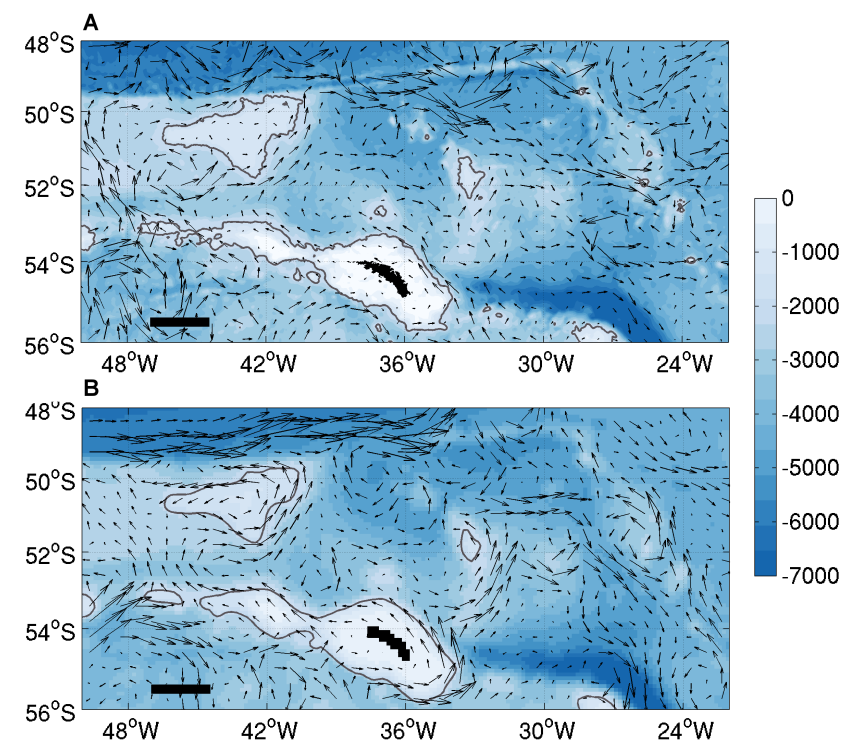

Fig. 4. Surface circulation (black arrows) in the South Georgia area, as obtained from (A) Aviso satellite altimetry for January-February 2008 and from (B) model results for January-February of the last modelling year. Background colours indicate bottom topography. For reference, the $2000 \mathrm{~m}$ bathymetry is indicated with thin lines. In both panels, the horizontal bar in the bottom-left corner indicates $1 \mathrm{~m} \mathrm{~s}^{-1}$, and corresponds to approximately $160 \mathrm{~km}$. Modelled surface circulation is interpolated onto the coarser grid resolution of satellite altimetry.

For the purposes of this study, which aims at understanding sources but also potential transport pathways of iron from and then around South Georgia, particularly important circulation features are (i) the current that flows westward around the northern shelf of the island towards the Georgia Basin, believed to transport iron-enriched waters from the shelf region towards the bloom area (Nielsdóttir et al., 2012); (ii) the intense cyclonic circulation along the borders of the Georgia Basin, which confines South Georgia blooms to the basin (Borrione and Schlitzer, 2013); and (iii) the flow through Black Rock Passage which delimits the southwestern border of South Georgia blooms and separates them from the waters adjacent to Shag Rocks (Venables et al., 2012). The level of realism reached by the simulated surface circulation during January and February (Fig. 4b) will be assessed considering these specific currents. Smaller-scale features, like eddies, filaments or meanders in the flow, are not considered in the comparison between altimetry and modelling results because they reflect the natural variability of the system, and can be very different according to the years considered.

In the model (Fig. 4b), surface circulation patterns around the island are strongly steered by bottom topography, and reflect in many ways circulation patterns described above (Fig. 4a). In fact, the model reproduces the current that, after flowing around the southeastern and then the northeastern shelf of the island (i.e. the SACCF), flows northeast of the island along the southern flank of the NEGR, or veers west travelling around the northern shelf of the island towards the Georgia Basin. Moreover, the model reproduces the northward current flowing through Shag Rock Passage.

Along the margins of the Georgia Basin the current is relatively intense $\left(20-40 \mathrm{~cm} \mathrm{~s}^{-1}\right)$, whereas over the central portion of the basin the current is generally weaker (10$15 \mathrm{~cm} \mathrm{~s}^{-1}$ ), except for a fast rotating anticyclonic eddy that is formed to the south west of the basin $\left(40^{\circ} \mathrm{W}, 53^{\circ} \mathrm{S}\right)$. This eddy is not present in the Aviso observations for JanuaryFebruary of 2008.

Modelled current intensities reproduce the general spatial variability observed in satellite altimetry and described previously by Ward et al., 2005 and Thorpe et al., 2002. For example, in both the modelled and observed circulation fields, surface currents are stronger along the margins than over the central part of the basin; overall, however, the model tends to overestimate absolute circulation velocities.

\subsection{Macronutrient concentrations}

Surface macronutrient $(0-30 \mathrm{~m})$ concentrations were averaged over the domain centred around the main South Georgia bloom area, defined between $45-32^{\circ} \mathrm{W}$ and $56-50^{\circ} \mathrm{S}$ (shown in Fig. 7a). Macronutrient concentrations follow a clear annual cycle both in the CARS2009 monthly climatology and in the monthly concentrations simulated by the model (Fig. 5). In both data sets, maximum silicate, nitrate, and phosphate concentrations occur between winter and early spring, while minimum values are recorded in late austral summer. In all cases surface macronutrient concentrations averaged over the chosen domain are above concentrations that are limiting for phytoplankton growth. For each monthly average, the SD is also indicated and reflects the spatial variability of macronutrient concentrations. The high variability is due to inclusion of water masses with different properties caused by their location relative to the ACC fronts or, during austral summer, due to different macronutrient utilization within in-bloom and out-bloom waters (see also Whitehouse et al., 2000). In the following, maximum and minimum values are reported with their corresponding $\mathrm{SD}$ and SE. Averages, SD and SE are rounded to the first decimal place.

In the two data sets the timing of maximum and minimum values in the annual cycles of silicate coincide (Fig. 5a). During September surface silicate concentrations reach their annual maximum value and rise to $25.1 \mu \mathrm{M}$ in the CARS2009 data set $(\mathrm{SD}=8.9 \mu \mathrm{M}$ and $\mathrm{SE}=0.5 \mu \mathrm{M})$ and in the model $(\mathrm{SD}=8.6 \mu \mathrm{M}$ and SE 0.1 $\mu \mathrm{M})$. In February, however, when silicate surface concentrations are at their minimum, concentrations are significantly different: in the CARS2009 data set concentrations are close to $7.2 \pm 5 \mu \mathrm{M}(\mathrm{SE}=0.3 \mu \mathrm{M})$ and correspond to approximately $28 \%$ of the maximum value recorded in September; conversely, the model silicate concentrations during February are almost twice those of the 

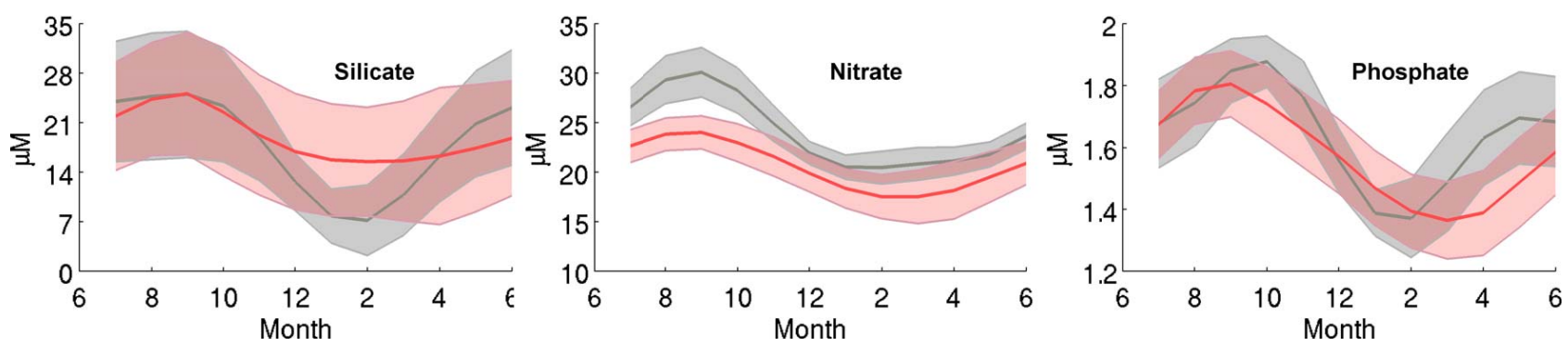

Fig. 5. Annual cycles of surface (0-30 m) silicate (A), nitrate (B) and phosphate (C) concentrations averaged over the South Georgia domain defined between $45-32^{\circ} \mathrm{W}$ and $56-50^{\circ} \mathrm{S}$ (shown in Fig. 7a) from the CARS2009 climatology (black lines) and from model outputs from the last modelling year of the SEDDUST scenario (red line). Shaded areas indicate the standard deviation of the averages.

CARS2009 data set; modelled silicate concentrations are close to $15.5 \pm 7.7 \mu \mathrm{M}(\mathrm{SE}=0.1 \mu \mathrm{M})$ and correspond to $62 \%$ of the maximum value recorded in September. Therefore, in the model there is a significantly weaker winter-summer reduction of silicate concentrations than in the CARS2009 observations, possibly due to the model's tendency to underestimate total Chl $a$ (see below) or to the model's range of admitted $\mathrm{Si} / \mathrm{C}$ ratios. Alternatively, thick-shelled diatoms based on recycled nitrogen and other nutrients can take up and sink $\mathrm{Si}$ without increasing Chl $a$ levels (Assmy et al. 2013).

As shown in Fig. 5b, the model matches the timing of maximum and minimum nitrate concentrations observed in the CARS2009 data set (i.e. September and February in both data sets) as well as the winter to summer nitrate concentration decrease (close to $30 \%$ of the winter value). However, compared to the CARS2009 surface nitrate concentrations, which range between $20.4 \pm 1.7 \mu \mathrm{M}$ in February $(\mathrm{SE}=0.1 \mu \mathrm{M})$ and $30.1 \pm 2.5 \mu \mathrm{M}$ in September $(\mathrm{SE}=0.1 \mu \mathrm{M})$, the annual cycle of modelled surface nitrate concentrations averaged over the South Georgia domain are approximately $4 \mu \mathrm{M}$ lower than observations: in the model, nitrate concentrations range between $17.5 \pm 2.2 \mu \mathrm{M}$ in February ( $\mathrm{SE} \sim 0 \mu \mathrm{M}$ ) and $24 \pm 1.7 \mu \mathrm{M}$ in September (SE $\sim 0 \mu \mathrm{M})$.

The annual cycles of CARS2009 and modelled phosphate concentrations averaged over the South Georgia domain are indicated in Fig. 5c. Observational and modelled phosphate concentrations range between very similar values: minimum values are in both cases $1.4 \pm 0.1 \mu \mathrm{M}$, while maximum concentrations are respectively $1.9 \pm 0.1 \mu \mathrm{M}$ and $1.8 \pm 0 \mu \mathrm{M}$. In the two data sets however, the months of minimum and maximum values differ: in the CARS2009 data set, they occur in February and October respectively, while in the model minimum and maximum values are observed in March and September respectively.

\subsection{Surface Chl $a$ concentrations}

During January-February of 2008, MODIS satellite estimates of surface Chl $a$ concentrations (Fig. 6a) reveal the presence of a large and intense phytoplankton bloom over the southern and northwestern shelf of South Georgia, and to the northwest and north of the island ( $\mathrm{Chl} a>2 \mathrm{mg} \mathrm{m}^{-3}$ ). The 2008 bloom reflects the typical geometry of the South Georgia bloom area described by Borrione and Schlitzer (2013). Outside all borders of the Georgia Basin and due east of the island, Chl $a$ values are close to or below $0.5 \mathrm{mg} \mathrm{m}^{-3}$ (HNLC waters). In this specific observation period, exceptions to the HNLC waters observed outside the main bloom area are the patches around $\left(42^{\circ} \mathrm{W}, 55^{\circ} \mathrm{S}\right),\left(49^{\circ} \mathrm{W}, 48^{\circ} \mathrm{S}\right)$ and $\left(24^{\circ} \mathrm{W}\right.$, $53^{\circ} \mathrm{S}$ ) where $\mathrm{Chl} a$ concentrations are above $0.75 \mathrm{mg} \mathrm{m}^{-3}$. The Chl $a$-rich patch around $\left(24^{\circ} \mathrm{W}, 53^{\circ} \mathrm{S}\right)$, which is more than $700 \mathrm{~km}$ east of the NEGR, is larger in size than the other patches, and appears to be connected to the main bloom area by a narrow filament, with $\mathrm{Chl} a$ concentrations close to $1 \mathrm{mg} \mathrm{m}^{-3}$.

Arrows in Fig. 6a represent contemporaneous surface circulation patterns from Aviso satellite altimetry (see also Sect. 4.1 and Fig. 4a). The joint analysis of the two data sets shows that the location and shape of the South Georgia bloom is strongly related to local circulation, which seems to also generate the narrow tongue of $\mathrm{Chl} a$-rich waters connecting the main bloom area to the $\mathrm{Chl} a$-rich patch observed around $\left(24^{\circ} \mathrm{W}, 53^{\circ} \mathrm{S}\right)$. Variability in flow intensity over the shelf of the island is reflected in the distribution of Chl $a$ concentrations. Surface circulation is weak $\left(<5 \mathrm{~cm} \mathrm{~s}^{-1}\right.$, see also Whitehouse et al., 2008 and Thorpe et al., 2002) over the western and southern shelf of the island and corresponds to the highest $\mathrm{Chl} a$ concentrations. In the northeastern portion of the shelf region, where $\mathrm{Chl} a$ concentrations are low $\left(<0.2 \mathrm{mg} \mathrm{m}^{-3}\right)$, surface currents flowing parallel to the shelf-break are above $10-15 \mathrm{~cm} \mathrm{~s}^{-1}$.

An example of a weaker South Georgia phytoplankton bloom is provided by January-February of 2011 (Fig. 6b) when Chl $a$ concentrations were mostly below $1.5 \mathrm{mg} \mathrm{m}^{-3}$. Nevertheless, patterns in Chl $a$ concentrations (i.e. location of bloom and non-bloom waters) and surface circulation around the island have many similarities with the patterns described for January-February of 2008 (Fig. 6a). A comparison of the model output (Fig. 6c) with satellite observations (Fig. 6a) demonstrates the ability of the model 


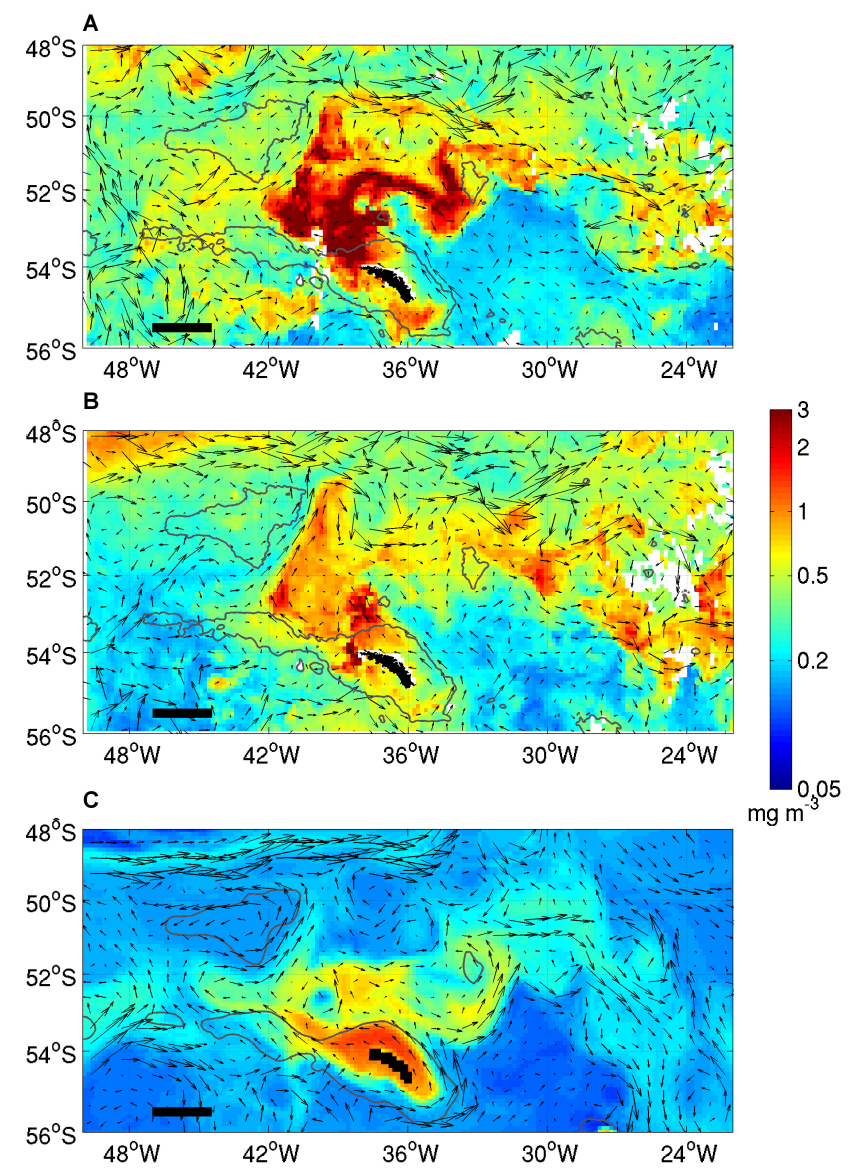

Fig. 6. Surface Chl $a$ concentrations in the South Georgia area as obtained from MODIS ocean colour estimates for JanuaryFebruary 2008 (A) and January-February 2011 (B). Satellite estimates are interpolated onto the model's coarser grid resolution. In (C) surface $(0-30 \mathrm{~m})$ averages of Chl $a$ concentrations from January-February of the last modelling year. In all cases, black arrows depict contemporaneous surface circulation patterns either from Aviso altimetry (in A and B) or from the model (in $\mathbf{C}$ ). Circulation patterns in panels $\mathbf{A}$ and $\mathbf{C}$ are equivalent to those depicted in Fig. 4. In all panels, the $2000 \mathrm{~m}$ bathymetry is indicated with thin lines; the horizontal bar in the bottom-left corner indicates $1 \mathrm{~m} \mathrm{~s}^{-1}$, and corresponds to approximately $160 \mathrm{~km}$.

to capture the main spatial features of Chl $a$ distributions in the South Georgia region. In both data sets highest levels are observed over the Georgia Basin and the shelf of the island, where concentrations are one order of magnitude higher than in the surrounding waters. The model captures the west-east extension of the phytoplankton bloom between the area north of Shag Rocks and the NEGR, and the north-south extension between the southern shelf-break of the island and the $50^{\circ} \mathrm{S}$ parallel. In agreement with satellite ocean colour imagery, ROMS_AGRIF-PISCES reproduces the long $(\sim 800 \mathrm{~km}) \mathrm{Chl} a$-rich plume extending eastwards of the NEGR, and also a region of higher concentrations along the Falkland Escarpment, to the northwest of the South
Georgia phytoplankton bloom. The current model configuration cannot reproduce individual years, but it adequately captures the relative magnitude of $\mathrm{Chl} a$ concentrations between bloom and non-bloom waters. However, the model tends to under-estimate absolute $\mathrm{Chl} a$ concentrations. Highest Chl $a$ concentrations in the model are mostly between $0.7-1.5 \mathrm{mg} \mathrm{m}^{-3}$ in the main bloom area, and never rise above $0.3 \mathrm{mg} \mathrm{m}^{-3}$ downstream of the NEGR, whereas observations indicate values $>2$ and $\sim 1 \mathrm{mg} \mathrm{m}^{-3}$ respectively. The model predicts high Chl $a$ concentrations over the northeast shelf of the island $\left(35^{\circ} \mathrm{W}, 54^{\circ} \mathrm{S}\right)$ where ocean colour estimates indicate recurrent low concentrations $\left(<0.5 \mathrm{mg} \mathrm{m}^{-3}\right)$. Furthermore, the observed bloom to the north and northeast of South Georgia occurs further north than in the model. As discussed in Sect. 5.3 below, possible causes for these discrepancies may be linked to the model's current spatial resolution and/or representation of the iron cycle.

Similar to our description of MODIS Chl $a$ concentrations and Aviso altimetry (Fig. 6a and b), there is a clear correspondence between $\mathrm{Chl} a$ patterns and local circulation evident in the modelled fields (Fig. 6c). In the simulations the South Georgia phytoplankton bloom is confined on all sides by bands of rapidly flowing currents $\left(20-40 \mathrm{~cm} \mathrm{~s}^{-1}\right)$, while the two Chl $a$-rich plumes observed along the Falkland Escarpment and downstream of the NEGR correspond to regions of very high flow velocities $\left(30-80 \mathrm{~cm} \mathrm{~s}^{-1}\right)$, which most likely are responsible for the position, shape and extension of the two Chl $a$-rich plumes. Over the southern portion of the Georgia Basin $\left(40^{\circ} \mathrm{W}, 53^{\circ} \mathrm{S}\right)$, amidst waters with high Chl $a$ concentrations, an anticyclonic eddy encircles waters with very low $\mathrm{Chl} a$ concentrations $\left(\sim 0.1 \mathrm{mg} \mathrm{m}^{-3}\right)$. Analysis of circulation and Chl $a$ concentration fields from previous modelled months indicates that the anticyclonic eddy detaches from a meander extending southwards from the $\mathrm{Chl}$ $a$-poor waters to the north of the Georgia Basin. A similar meander is observed in satellite imagery of January 2004 (Borrione and Schlitzer, 2013).

\subsection{DFe concentrations}

Surface $(\sim 3 \mathrm{~m})$ underway $\mathrm{dFe}$ concentrations (Fig. 7a, see also Nielsdóttir et al., 2012) were measured between January and February 2008 in the area south of South Georgia $\left(\sim 41^{\circ} \mathrm{W}, 55^{\circ} \mathrm{S}\right)$, along a transect across the Georgia Basin, and over the northern shelf of the island. Surface $\mathrm{dFe}$ concentrations were highest over the shelf of the island, ranging between 2.5 and $6.9 \mathrm{nM}$ and then decreased to concentrations of approximately $1 \mathrm{nM}$ close to the $2000 \mathrm{~m}$ bathymetry contour. Over the Georgia Basin, concentrations were variable and ranged between values close to the instrumental detection limit $(0.027 \pm 0.018 \mathrm{nM})$ and high concentrations (i.e. $2 \mathrm{nM}$ at $38^{\circ} \mathrm{W}, 52.5^{\circ} \mathrm{S}$ ). South of South Georgia (i.e. upstream of the island) $\mathrm{dFe}$ concentrations were very low $(\leq 0.1 \mathrm{nM})$ at all sampled locations. DFe concentrations measured in the locations marked in Fig. 7a are also depicted 

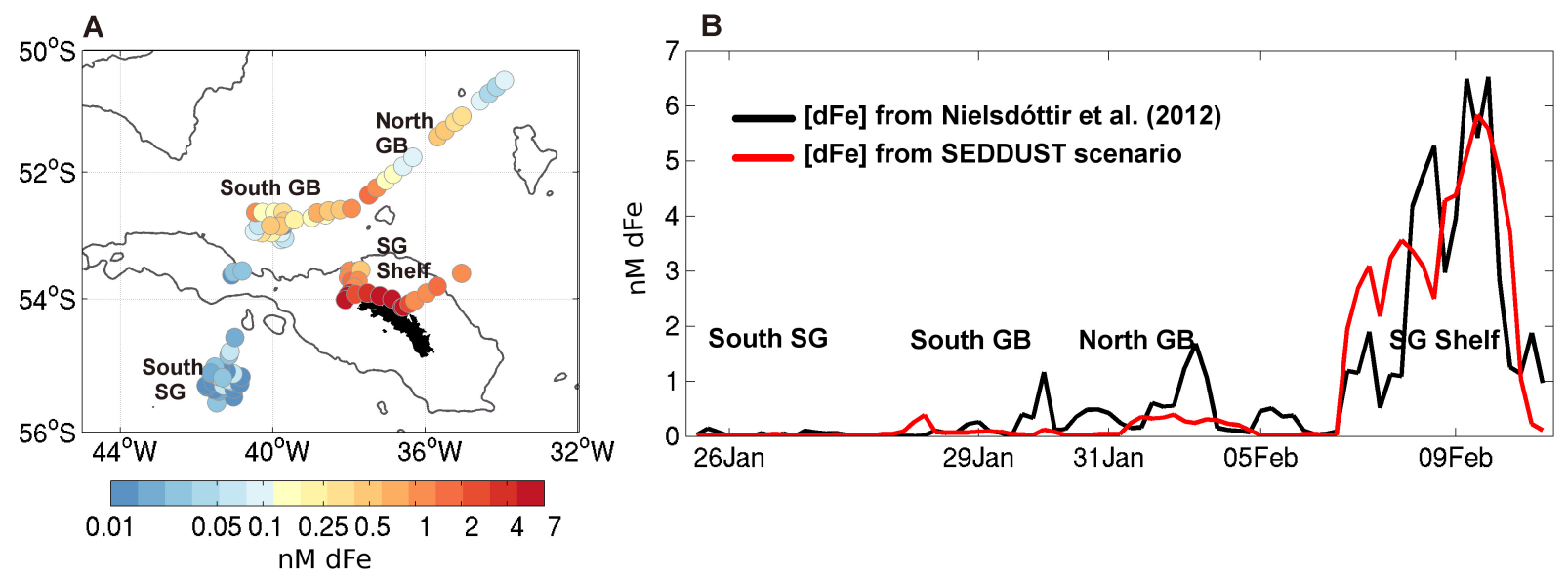

Fig. 7. (A) Location and concentrations of dFe underway measurement from January and February of 2008 (Nielsdóttir et al., 2012). Depth profiles of $\mathrm{dFe}$ were taken south of the island in the area denoted as South SG (around $41.24^{\circ} \mathrm{W}, 55.21^{\circ} \mathrm{S}$ ) and to the north of the island, in the area denoted as South GB (around $40.10^{\circ} \mathrm{W}, 52.86^{\circ} \mathrm{S}$ ). (B) Underway measurement of dFe (red line) and simulated surface dFe concentrations (black line); model values were interpolated onto the dFe sampling locations shown in panel A. For reference, the $x$ axis indicates dates of in situ dFe sampling. The main geographical areas are also indicated and correspond to those marked in panel A.

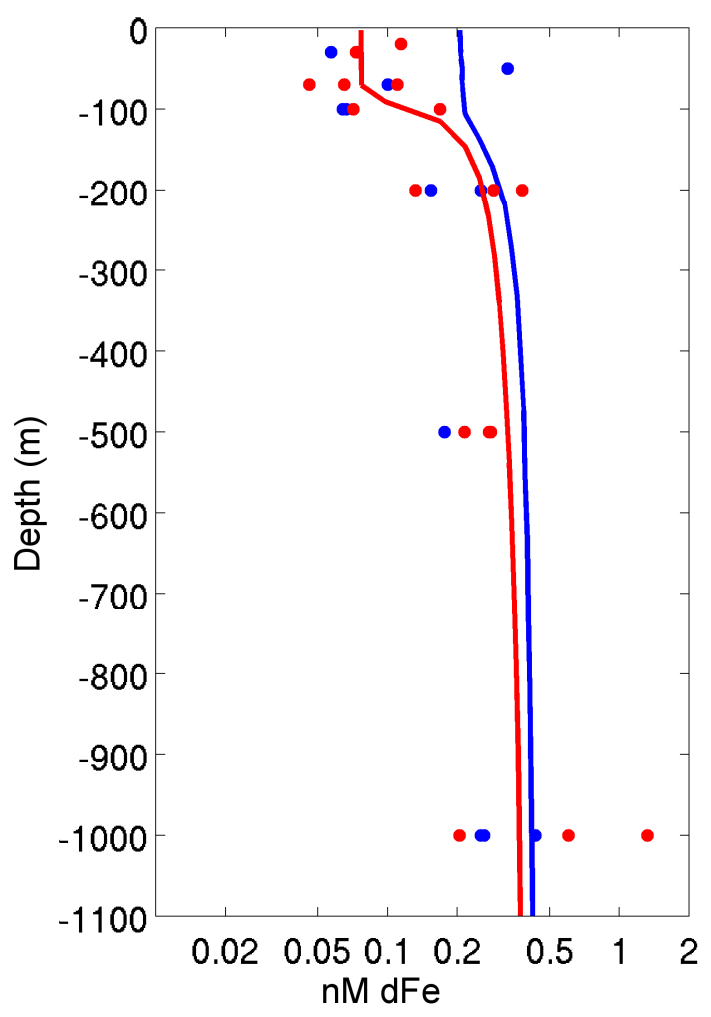

Fig. 8. DFe concentrations downstream (around $40.10^{\circ} \mathrm{W}$, $52.86^{\circ} \mathrm{S}$, in blue) and upstream (around $41.24^{\circ} \mathrm{W}, 55.21^{\circ} \mathrm{S}$, in red) of South Georgia as from modelling results during November of the last modelling year (lines) and from observations reported by Nielsdóttir et al. (2012) during November 2006 (dots). in Fig. 7b, following their sampling progression for a more detailed comparison with model results. DFe depth profiles $(0-1000 \mathrm{~m})$ were taken to the south and north of the island (Fig. 8). Measured dFe concentrations were comparable for the two regions, with low concentrations close to the surface $(<0.1 \mathrm{nM})$ increasing with depth.

Modelled surface $(0-30 \mathrm{~m})$ and vertical profiles of $\mathrm{dFe}$ concentrations (SEDDUST scenario) were interpolated onto the same sampling locations in order to maintain the correspondence between $\mathrm{dFe}$ concentrations and local topography (i.e. distance from the island or ocean depth). As model results cannot be representative of any specific observational year, our comparison will aim at verifying that the model can reproduce the regional large-scale patterns of high and low $\mathrm{dFe}$ concentrations observed in the underway data, as well as the vertical, nutrient-like $\mathrm{dFe}$ profile observed to the north and south of the island. Mesoscale features like eddies may cause significant variability (Nielsdóttir et al. 2012).

Both in the observations and modelling results (Fig. 7b) surface $\mathrm{dFe}$ concentrations increase progressively from the area upstream of South Georgia (on average, $\mathrm{dFe}<0.1 \mathrm{nM}$ ), to the Georgia Basin (on average, dFe concentrations between $0.5 \mathrm{nM}$ and $2 \mathrm{nM}$ ) and finally to the area over the shelf of the island, where concentrations are maximum in both data sets (on average, dFe concentrations range between $1.5 \mathrm{nM}$ and $6 \mathrm{nM}$ ). Differences in the modelled and sampled $\mathrm{dFe}$ concentrations, as for example over the southern part of the Georgia Basin (indicated as South GB in Fig. 7), depend on differences between surface circulation patterns in the two data sets: comparing Fig. 6c with Fig. 6a, it can be seen that around $\left(40^{\circ} \mathrm{W}, 53^{\circ} \mathrm{S}\right)$ model results indicate the presence of an anticyclonic eddy which is not present in the 
surface circulation patterns obtained from satellite altimetry for 2008.

Depth profiles of measured and modelled dFe concentrations (dots and solid lines in Fig. 8) are also in agreement, especially at depths below the surface layer influenced by the seasonal biological uptake of iron. Both upstream and downstream of South Georgia, modelled $\mathrm{dFe}$ concentrations increase with depth and fall in the range of measurements reported by Nielsdóttir et al., 2012, but also by de Jong et al. (2012) in other regions of the Southern Ocean.

On average, the difference between modelled and measured dFe concentrations in the locations marked in Fig. 7a is $\sim 0.02 \mathrm{nM}$, with root mean square (rms) close to $0.81 \mathrm{nM}$. Similar values were also obtained when $\mathrm{dFe}$ concentrations were extracted from the austral summers of the two previous modelling years (data not shown): in the previous years the calculated mean difference is $\sim 0.01 \mathrm{nM}$ and the rms is close to $1 \mathrm{nM}$. These low values demonstrate that in the present configuration, the model can reproduce adequately the main features of the distribution of $\mathrm{dFe}$ concentrations in the region; moreover, similar to the in situ data set, modelled $\mathrm{dFe}$ concentrations are minimum at the surface of the ocean and to the south, i.e. upstream of the island and reach their maxima in the deep ocean, and along the coastal area.

Clearly, modelling results can provide a picture at uniform spatial resolution $(\sim 11 \mathrm{~km})$ of surface $\mathrm{dFe}$ concentrations also outside the locations indicated in Fig. 7a. During January and February of the last modelling year, surface dFe concentrations (Fig. 9a) are $<0.1 \mathrm{nM}$ in most of the South Georgia domain, except for a large area over the shelf and to the north and northeast of the island and over a narrow area along the Falkland Escarpment, located to the northwest of South Georgia.

Over the shelf of South Georgia dFe concentrations are overall $>2 \mathrm{nM}$, with highest values along the coast $(2-$ $8 \mathrm{nM})$. An iron-rich plume $(\sim 0.5 \mathrm{nM})$ originates from the northwestern corner of the shelf and extends westward along the northern flank of Shag Rocks; a second dFe plume originates from the northeastern shelf of the island and extends northeastward along the flanks of the NEGR. The latter plume continues further east along the Islas Orcadas Rise for approximately $800 \mathrm{~km}$, until $\mathrm{dFe}$ concentrations reach background values $(<0.1 \mathrm{nM})$. Both plumes are clearly dependent on the direction of flow, which here moves away from the island, and its high velocities $\left(\sim 20-50 \mathrm{~cm} \mathrm{~s}^{-1}\right)$. Conversely, to the south and east of the island, surface $\mathrm{dFe}$ concentrations decrease rapidly to background concentrations $(<0.1 \mathrm{nM})$, remaining high only along a narrow band over the southern shelf of the island; such limited extension is due to the local currents which here move northward, pushing surface waters towards the coast, and then east.

The scale length (Johnson et al., 1997) provides a way to quantify the decrease of iron with distance; its value accounts for all processes acting to increase or decrease surface $\mathrm{dFe}$ concentrations, without discriminating between them.
The scale length of $\mathrm{dFe}$ transport is defined as the distance over which an initial reference concentration (RC) drops to $1 / e$. RC. For our calculations, as reference we use the average $\mathrm{dFe}$ concentration along the coast of the island (i.e. $3.68 \mathrm{nM}$ ). In Fig. 9b (detail of Fig. 9a) the position of dFe concentrations equal to $1 / e \cdot 3.68 \mathrm{nM}$ (i.e. $1.35 \mathrm{nM}$ ) is traced with a thick contour line. The $\mathrm{dFe}$ scale length corresponds to the distance between the coast of the island and the $1.35 \mathrm{nM}$ contour line.

In the chosen time period, modelling results clearly show that the scale length of dFe concentrations is a dynamic property, and that it can vary by a factor of 5 depending on the direction and intensity of local circulation. In fact, to the south of the island, where the flow pushes surface waters towards the coast and then to the east, the scale length is at its minimum values $(\sim 20 \mathrm{~km})$, while to the northwest of South Georgia, where local circulation is directed away from the island towards the Georgia Basin, the scale length reaches its maximum values $(\sim 110 \mathrm{~km})$.

\subsection{Iron sources around South Georgia}

\subsubsection{Atmospheric sources of iron}

Scale lengths ranging between 20 and $110 \mathrm{~km}$ have clearly shown that South Georgia is the core of the dFe plume observed in the region. However, as South Georgia is located along the main trajectory of dust plumes originating from the Patagonian Desert (Mahowald et al., 2005; Ginoux et al., 2001; Johnson et al., 2010) dust deposition may also be a relevant source of iron to the surface waters around the island.

The importance of dust-derived $\mathrm{dFe}$ to the surface layer was evaluated by comparing results from the reference SEDDUST scenario with the SED_NODUST sensitivity run. Surface $\mathrm{dFe}$ concentrations obtained with the two simulations and extracted along the virtual transect line traced in Fig. 9a are marked respectively with a solid and dashed red line in Fig. 9c. The transect line was chosen in order to consider regions of the South Georgia domain which are closer or farther from the island or the Patagonian Desert, and hence likely differ on the relative importance of sedimentary or dust sources of iron. Results depicted in Fig. 9c indicate that along the transect east of $\sim 48^{\circ} \mathrm{W}$, the contribution of $\mathrm{dFe}$ from dust deposition is approximately $0.01 \mathrm{nM}$, hence negligible when compared to surface concentrations from the SEDDUST run, especially over the Georgia Basin. Conversely, in the area around $\left(49^{\circ} \mathrm{W}, 48^{\circ} \mathrm{S}\right)$, at the northwestern corner of the South Georgia domain, atmospheric deposition is the principal source of $\mathrm{dFe}$ to the region; in fact, in the SEDDUST simulation, $\mathrm{dFe}$ concentrations are $\sim 0.1 \mathrm{nM}$, but drop to values close to zero when the dust source of iron is removed. 

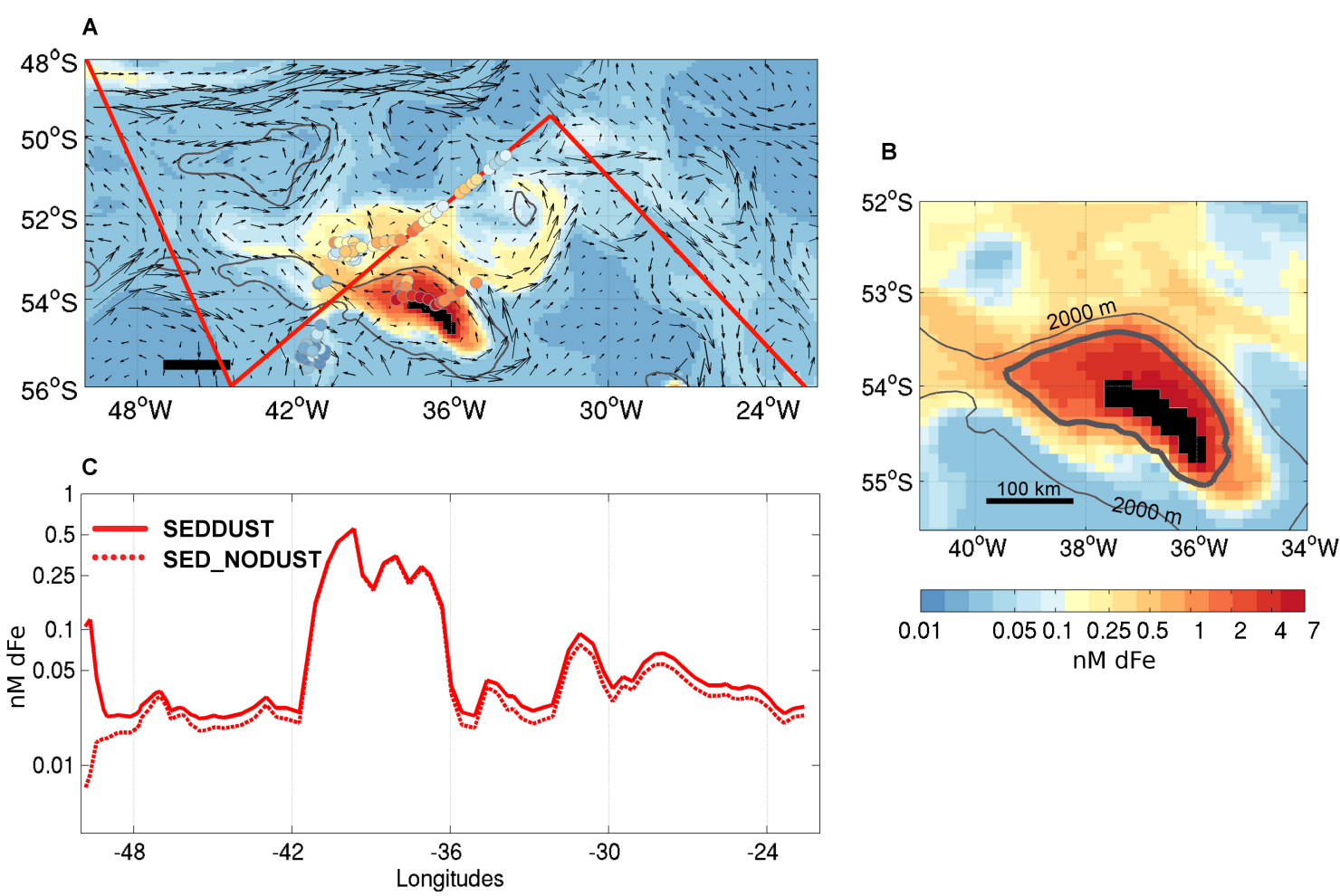

Fig. 9. Simulated surface $(0-30 \mathrm{~m}) \mathrm{dFe}$ concentrations for January-February of the last modelling year. In (A) dFe concentrations (colourscale as in B) are obtained from the SEDDUST scenario; coloured dots indicate in situ surface dFe concentrations measured by Nielsdóttir et al. (2012), shown also in Fig. 7a. The red line marks a virtual transect along which are extracted modelled dFe concentrations depicted in $\mathbf{C}$; black arrows represent the contemporaneous surface circulation as depicted in Fig. 4b; the horizontal bar indicates $1 \mathrm{~m} \mathrm{~s}^{-1}$ and corresponds to approximately $160 \mathrm{~km}$. (B) $\mathrm{dFe}$ concentrations from the SEDDUST scenario (detail from panel A); the thick contour line indicates dFe concentrations equal to $1.35 \mathrm{nM}$, here marked to estimate $\mathrm{dFe}$ scale lengths; see text for more details. (C) Modelled dFe concentrations for points along the red line drawn in A. Solid line depicts values obtained from the SEDDUST scenario (i.e. including sedimentary and atmospheric deposition of $\mathrm{dFe}$ ), dashed line depicts dFe values obtained from the SED_NODUST scenario where there is no atmospheric deposition of $\mathrm{dFe}$.

The greater importance of sedimentary versus atmospheric sources of iron in the domain centred around the main bloom area (Fig. 7a) is confirmed by averaged surface dFe and Chl $a$ concentrations obtained either with the SEDDUST or SED_NODUST simulation. As shown in Table 1, average values from the SED_NODUST simulation are only slightly lower than those obtained with the SEDDUST run. Moreover, the integrated dust deposition of $\mathrm{dFe}$ over the same domain $(\sim 2200 \mathrm{~km}$ away from South America) is $\sim 6.27 \times 10^{9} \mu \mathrm{M} \mathrm{day}^{-1}$, while the flux of sedimentary iron released into the water column from all sediments shallower than $100 \mathrm{~m}$ is $1.35 \times 10^{11} \mu \mathrm{M}$ day $^{-1}$. Nevertheless, it must be noted that although the flux estimates presented above are useful for an estimate of the relative importance of the two iron sources around South Georgia, their absolute values must be considered with care because model results rely on our current knowledge (and uncertainties, see Sects. 5.2 and 5.3) of the iron cycle, and may largely depend on the chosen model parameters (i.e. content and solubility of iron in dust, or maximum $\mathrm{dFe}$ flux from the sediments).

\subsubsection{Sedimentary sources of iron}

Results presented in the previous section have indicated that in the model, sediments around South Georgia release almost all of the iron observed around and then downstream of the island. Therefore, sensitivity runs were used to estimate the depth of the most significant sedimentary sources. For this purpose, in each sensitivity run only sediments from a selected depth range could act as sources of iron, while at all other depths the iron flux was set to $0 \mu \mathrm{M} \mathrm{m}^{-2} \mathrm{day}^{-1}$. Surface $\mathrm{dFe}$ and $\mathrm{Chl} a$ concentrations obtained from the reference SEDDUST simulation and each sensitivity run were averaged over the domain centred around the main bloom area (Fig. 7a). Results are compared in Table 1 and depicted in Fig. 10.

With the chosen horizontal and vertical resolution and the resulting model's bathymetry each selected depth layer accounts for comparable sediment surface areas at depth ranges shallower than $50 \mathrm{~m}$ (see Sect. 2.3). Indeed, in this configuration each sediment surface area cannot be equivalent to the 

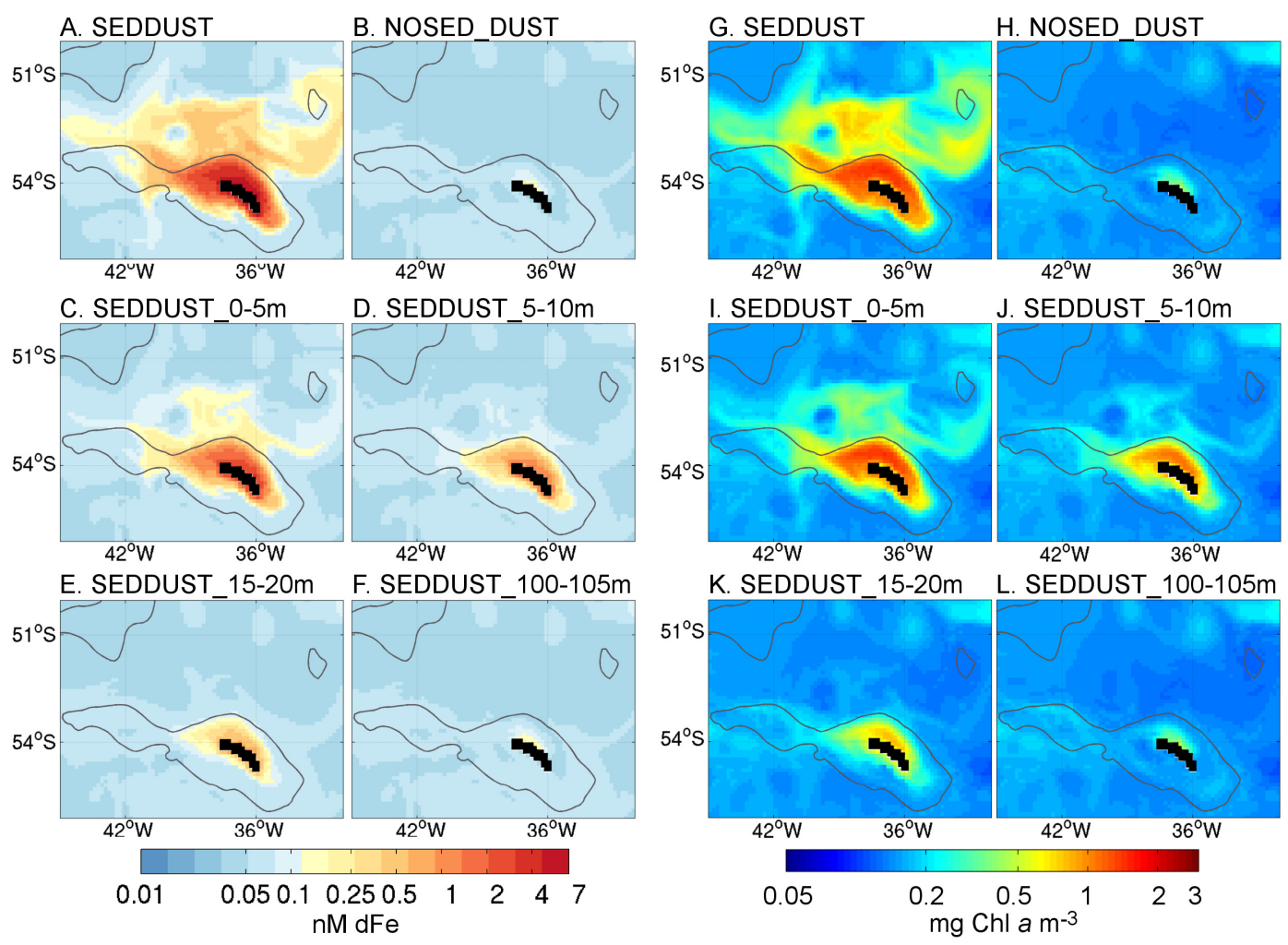

Fig. 10. Surface ( $(0-30 \mathrm{~m}) \mathrm{dFe}$ concentrations (panels a-f on the left) and Chl $a$ concentrations (panels $\mathbf{g}-\mathbf{l}$ on the right) for January-February of the last modelling year obtained with simulations, including different sedimentary sources of iron. Results for the reference runs (i.e. SEDDUST and NOSED_DUST) are shown in the first row. See also Table 1 and Sect. 2.3 for further details on each simulation.

surfaces one would measure around the island, because in the model the bathymetry is smoothed, and, by construction, it is vertical at the coastline. Nevertheless, for the purposes of this series of model experiments this configuration allows a more objective comparison between sensitivity runs, implicitly correcting for variations only due to different sediment surface areas.

Results suggest that the island's coast and very shallow sediments (i.e. depths $\leq 5 \mathrm{~m}$ ) account for most of the surface $\mathrm{dFe}$ and Chl $a$ concentrations simulated with the SEDDUST scenario, followed in importance by sedimentary sources from the 5-20 m depth interval. Conversely, when the release of $\mathrm{dFe}$ occurs at greater depths only, the model generates a weak and localized surface $\mathrm{dFe}$ and $\mathrm{Chl} a$ plume (not shown), reflected in $\mathrm{dFe}$ and $\mathrm{Chl} a$ values that become progressively similar to those obtained with the NOSED_DUST simulation (Table 1). Moreover, surface $\mathrm{dFe}$ and $\mathrm{Chl} a$ concentrations obtained with the SEDDUST_100-105 m simulation (Fig. 10f and l) are almost identical to those obtained with the NOSED_DUST simulation (Fig. 10b and h) showing that deeper sediments have a negligible influence on surface iron distributions. The similarity of the latter results is further confirmed by rms and mean differences calculated between the two runs (last row of Table 1).
Although these sensitivity tests are very useful for an estimate of the relative importance of sedimentary sources of iron at different depths, it must be stressed that because in the present model configuration there is no effect of tidal mixing, and the chosen resolution does not allow the representation of vertical mixing generated at the meso- and sub-mesoscale, the contribution from the deeper layers could be largely underestimated (Blain et al., 2008).

\section{Discussion}

\subsection{The South Georgia island mass effect}

Results obtained with ROMS_AGRIF-PISCES show that enhanced Chl $a$ concentrations are only found downstream of South Georgia, i.e. to the north and then northeast of the island, suggesting that the South Georgia island mass effect, and not processes acting upstream of the island, stimulate the observed blooms. Korb et al (2004) reached a similar conclusion by comparing the spatial variability of phytoplankton blooms from in situ and satellite-based observations. In the model, South Georgia phytoplankton blooms extend in the easterly direction for more than $800 \mathrm{~km}$ following the direction of the main flow and decrease in magnitude with distance from the island. Such long ranges are in 
agreement with previous satellite-based studies, and in particular with those of Korb et al. (2004) who observed that the South Georgia bloom can extend to the $0^{\circ}$ meridian, for distances $>2700 \mathrm{~km}$ aligned to the main path of the PF (see also Venables et al., 2012). Moreover, our modelling results capture the main features of $\mathrm{dFe}$ distribution and adequately reproduce absolute $\mathrm{dFe}$ concentrations (Figs. 7 and 8; rms $0.81 \mathrm{nM})$. Consequently, the model can provide a comprehensive view of surface $\mathrm{dFe}$ concentrations in the region during the productive season, hence compensating the current lack of large-scale and spatially uniform in situ measurements.

As one might hypothesize from surface Chl $a$ concentration patterns, the modelled $\mathrm{dFe}$ plume extends over a large area to the north and then northeast of the island following local circulation. As previously measured around South Georgia (Nielsdóttir et al., 2012, Holeton et al., 2005), but also in other regions of the Southern Ocean (e.g. Ardelan et al., 2010; Bucciarelli et al., 2001; Planquette et al., 2007), the model depicts highest $\mathrm{dFe}$ concentrations in near-shore waters $(>5 \mathrm{nM})$, decreasing with distance from the island. Our model results clearly show that the South Georgia island mass effect can reach regions located far away from the island $(>1000 \mathrm{~km}$ ), where $\mathrm{dFe}$ concentrations may still be above background concentrations. A comparable long-range influence of coastal regions has been previously suggested in other open-ocean regions of the world ocean, including the Southern Ocean (Elrod et al., 2004; Lam et al., 2006; de Jong et al., 2012; Moore and Braucher, 2008).

DFe scale length values, calculated from our model results as the distances over which an initial reference concentration drops to $1 / e$ of its initial value (Johnson et al., 1997), vary between $20 \mathrm{~km}$ and $110 \mathrm{~km}$. These values include the wide range of scale lengths obtained from in situ $\mathrm{dFe}$ observations in the open ocean and near-shore regions of the Southern Ocean. Smallest values were obtained by Ardelan et al (2010) around the Antarctic Peninsula, and by Planquette et al. (2007) around the Crozet Islands ( $\sim 25 \mathrm{~km}$ in both studies); larger-scale lengths were calculated around South Georgia by Nielsdóttir et al. (2012) and in the vicinity of the Kerguelen Islands by Bucciarelli et al. (2001) (scale lengths respectively $102 \mathrm{~km}$ and $151 \mathrm{~km}$ ). As shown in our model results around South Georgia (Fig. 9a) and by Ardelan et al. (2010) and Planquette et al. (2007) from in situ estimates, $\mathrm{dFe}$ scale lengths are variable and dependant on the direction and speed of local circulation. Clearly, it is important to keep in mind that scale length values do not depend on surface circulation only, but can be influenced by all processes that decrease or increase $\mathrm{dFe}$ concentrations between the source region and the points where scale lengths are measured (i.e. dilution, biological uptake; Nielsdóttir et al., 2012). Nevertheless, scale length calculations alone cannot discriminate between them.

\subsection{Atmospheric and sedimentary sources of iron}

In PISCES, dFe is supplied to the ocean from atmospheric dust-deposition and sediment mobilization (Fig. 3; Aumont and Bopp, 2006). Compared to the reference SEDDUST scenario, model results obtained neglecting atmospheric sources of iron (SED_NODUST simulation) show that there is a very small reduction $(<1 \%)$ in surface iron concentrations over the main phytoplankton bloom area (Fig. 9c), reflected in a negligible change in surface $\mathrm{Chl} a$ concentrations. To the best of our knowledge, in situ measurements of dust-derived iron deposition around South Georgia are presently not available for a comparison with our results. Dust deposition, for example, could be responsible for the isolated patches of Chl $a$ rich waters observed around South Georgia (Fig. 6a). There is still no information on local dust sources, which could be important considering that large parts of the island are barren and strong winds are frequent. However, there are numerous reasons to suggest that at least over the main bloom area local dust sources may be negligible compared to sedimentary sources. Westerly winds prevail around South Georgia (Chelton et al., 2004), therefore most of the local dust will likely be transported eastwards, while South Georgia blooms develop mostly to the north of the island. The main bloom area occurs relatively close to the island (few hundred kilometers), therefore deposited local dust would have experienced limited atmospheric ageing, an important factor increasing the solubility of iron in dust (i.e. Baker and Croot, 2010; Johnson et al., 2010; Mahowald et al., 2005). Finally, and perhaps most convincingly, the typical bloom area (Borrione and Schlitzer, 2013) agrees in shape and location with the iron plume simulated by the model and which is shown to originate from sedimentary sources around the island. Satellite estimates of atmospheric dust around or from South Georgia suffer from persistent cloud cover and are hence of limited use in this region (Gassó and Stein, 2007). Therefore, in situ measurements (similar to those of Heimburger et al., 2012 in the Kerguelen region) are required to corroborate or disprove our statements on the importance of dust in the region. In any case, when available, they will improve the current modelled representation of dust emission and transport in the Southern Ocean (i.e. Tegen and Fung, 1995; Ginoux et al., 2001; Mahowald et al., 2005; Li et al., 2008; Johnson et al., 2010).

The limited role of dust deposition on the iron budget and primary productivity was previously described by Meskhidze et al. (2007): combining model-based fluxes of mineral dust deposition and satellite-based surface $\mathrm{Chl} a$ concentrations between March 2000 and January 2004, they observed that the sole deposition of dust from the Patagonian Desert does not provide the major input of iron to the South Georgia region. The agreement between our and their study most likely resides in the fact that local circulation provides a continuous supply of sedimentary iron that can maintain high $\mathrm{dFe}$ concentrations throughout the productive season (Nielsdóttir et al., 2012). Under these conditions, any additional input 
of iron will have negligible effects on existing dFe concentrations. Conversely, outside the area influenced by any sedimentary input of iron from the island, surface background $\mathrm{dFe}$ concentrations are very low $(<0.1 \mathrm{nM})$ and any additional input of iron, including from dust deposition, can modify initial concentrations and stimulate phytoplankton growth. The importance of aeolian deposition of iron in regions that are land-remote and upstream sedimentary sources is in agreement with previous observations or modelling results for larger-scale or global studies (Johnson et al., 2010; Tagliabue et al., 2009; Moore and Braucher, 2008).

Nevertheless, as reviewed by Mahowald et al. (2005), there are still many uncertainties in the current knowledge of the life cycle of dust particles, from their release into the atmosphere to their transport and deposition on the ocean's surface, as well as on their interaction with the biological compartment (i.e. bacterial, phytoplankton or grazers' activity; Baker and Croot, 2010). Therefore, when interpreting model results one must keep in mind that under natural conditions dust-deposition, as well as its solubility and iron content, may be very different from the estimates used in this study (Sect. 2.2). For example, dust-deposition is derived from the climatology of Tegen and Fung (1995) implying constancy over years. However, dust storms from arid regions are episodic and variable in their magnitude (Johnson et al., 2010), therefore the climatology of Tegen and Fung (1995) will likely misrepresent the natural spatial and temporal variability. Moreover, Johnson et al. (2010) show that variations in dust mineralogy, in particular $\mathrm{CaCO}_{3}$ content, can influence the solubility of iron in dust, because $\mathrm{CaCO}_{3}$ effectively buffers the acidification of mineral aerosols during atmospheric transport. Numerous authors identify acidification of aerosols as a key process increasing solubility of iron during atmospheric transport (Baker and Croot, 2010; Johnson et al., 2010; Mahowald et al., 2005). Once in seawater, a combination of post-depositional agents (Baker and Croot, 2010), including photochemical reactions, complexation with ligands and interaction with all size classes of biology (from bacteria to zooplankton, see also Tovar-Sanchez et al., 2007) can increase iron solubility. Where primary productivity is highest (i.e. the main bloom area), biology and higher ligand concentrations (Hunter et al., 2007) are likely to increase the contribution of iron from dust-deposition. Nevertheless, if solubility of iron in dust was increased from $2 \%$ to $10 \%$, the contribution of dust deposition over the main bloom area would rise to $0.05 \mathrm{nM}$, but still remain below the contribution of iron from sedimentary sources considered alone (i.e. $0.5 \mathrm{nM})$.

As described in Sect. 4.4 (Figs. $7 \mathrm{~b}$ and 8), model results are able to capture the main features of $\mathrm{dFe}$ concentrations around the island, and suggest that the very shallow sediments provide most of the iron observed around and downstream of the island. However, the importance of deeper sediments could be underestimated because of the necessary simplification of bathymetry around the island (i.e. vertical bathymetry around the coastline and smoothed topography, see Sect. 2.3), which cannot represent accurately the actual sediment surface areas releasing iron to the water column. Moreover, the absence of tidal forcing as well as the current coarse model resolution will likely lead to an underestimation of all the fine-scale mechanisms that can mix and dilute the highly enriched coastal waters and control the spatial variability of biogeochemical properties around the island (i.e. continental shelf waves, cross-shelf or vertical mixing; Young et al., 2011). Over the island's shelf region the model produces an average mixed layer depth of about $20 \mathrm{~m}$. This value is very close to the mixed layer depth estimated in austral summer by Ward et al., 2005 over the northwestern shelf of the island; however, it is below values estimated by Korb et al., 2012 and simulated by Young et al., 2011 who used a model with a $3 \mathrm{~km}$ resolution validated with a very extensive data set of in situ temperature and salinity measurements.

Reduced horizontal and vertical mixing could explain, for example, the quite homogeneous distribution of $\mathrm{Chl} a$ and $\mathrm{dFe}$ concentrations around most of the island (Figs. $6 \mathrm{c}$ and 9a). Specifically, over the eastern shelf of the island $\left(35^{\circ} \mathrm{W}\right.$, $54^{\circ} \mathrm{S}$ ) where the model overestimates $\mathrm{Chl} a$ concentrations, the low resolution could lead to a misrepresentation of local circulation and the SACCF's influence in the region (Meredith et al., 2005). Other factors, however, could lead to this discrepancy. In the same area, in fact, Chelton et al. (2004) has described the presence of a recurrent wind shadow not captured in the model's wind forcing monthly climatology. Weaker winds reduce mixing processes (Meredith et al., 2005) but also generate a microclimate with greater sunshine and higher local air temperatures (Brandon et al., 1999) that will locally modify the properties and vertical structure of the water column. Moreover, Brandon et al., 1999 and Whitehouse et al., 2009 indicated that the eastern shelf region of the island is rich in biological activity, therefore topdown controls by macrozooplankton like krill, not included in the model (Fig. 3) could also locally control phytoplankton biomass.

With the current model configuration we cannot discriminate between all potential physical and chemical processes introducing iron around the island. However, considering the characteristic topography, landscape and circulation around South Georgia, we expect the concomitant effect of the processes schematically represented in Fig. 11. We can distinguish two major categories: processes acting on land or along the coast (i.e. precipitation and run-off) responsible for the input of iron present or deposited on land, and processes acting in the ocean, due to physical, biological or chemical processes occurring in the water column or at the sedimentwater interface.

South Georgia is a mountainous and largely barren island, with an irregular coastline and rugged topography. Most of the island's surface is recurrently or permanently covered by snow and ice (Gordon et al., 2008). During austral summer, rain, melting snow and glaciers most likely have a double 


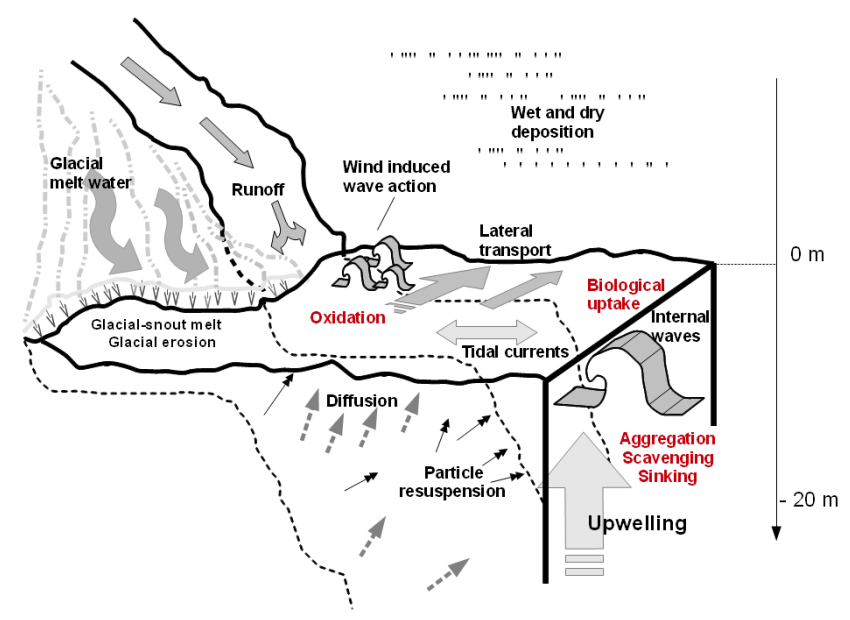

Fig. 11. Schematic overview of the potential coastal and shelf processes leading to the surface distribution of $\mathrm{dFe}$ observed around South Georgia (i.e. Fig. 9). Processes removing dFe from the water column are indicated in red.

effect on iron input to the ocean: meltwater not only can carry dust particles accumulated during winter, but, together with rain, it can feed local creeks, which hence have a stronger erosion effect on soil. Indeed, because many glaciers terminate at the coast or calve into the sea, glacier-scoured debris and glacier calving can provide an additional input of trapped soil particles and/or dust to the ocean, leading to a significant increase in local dFe concentrations (Raiswell et al., 2008; Lannuzel et al., 2007). DFe concentrations reaching $1.31 \mathrm{nM}$ in the Admunsen Sea (see Gerringa et al., 2012) provide evidence for such processes. Similar estimates are not available for South Georgia, although Landsat satellite images of the region (see Fig. 3 in Young et al., 2011) show extensive plumes of fine-sized particles and glacial flour all around the island, confirming the relevance of glacier melt.

As input of iron from glacier melt is independent from sedimentary and aeolian sources, we can make an estimate of its importance around South Georgia, adding maximum values measured by Gerringa et al. (2012) to our surface and coastal estimates of $\mathrm{dFe}$ concentrations. Resulting surface $\mathrm{dFe}$ concentrations compare better to underway $\mathrm{dFe}$ concentrations over the shelf of the island (Nielsdóttir et al., 2012); however a dedicated new modelling configuration that includes freshwater fluxes and iron release from melting ice (see Taylor et al., 2013) would certainly improve the confidence of these simplified estimates.

In PISCES the sedimentary sources of iron are simulated considering reductive mobilization (Aumont and Bopp, 2006), which has been recognized as a significant source of $\mathrm{dFe}$ to the oceans. Recent studies (i.e. de Jong et al., 2012; Klunder et al., 2011) suggest that the increase in dFe concentrations observed in measurements closer to the seafloor most likely derive from reductive mobilization of iron. In particular, below very productive surface waters such as those around South Georgia, the bacterial oxidation of deposited organic matter leads to reducing conditions at the sediment surface, consequently decreasing the oxygen penetration depth and hence increasing benthic $\mathrm{dFe}$ fluxes (Elrod et al., 2004). However, reductive mobilization of iron from the sediments is only one of the mechanisms believed to introduce $\mathrm{dFe}$ to the ocean interior. At the sediment-water interface, in fact, the remineralization of sediments resuspended by bottom or tidal currents (Young et al., 2011; Blain et al., 2008), internal wave activity (Blain et al., 2008) or wind-induced wave action (Gargett et al., 2004; de Jong et al., 2012) can introduce additional $\mathrm{dFe}$ to the water column (Fig. 11).

The total amount of $\mathrm{dFe}$ that ultimately leaves the bottom layer towards the surface depends on multiple concomitant factors, including the magnitude of bottom friction resuspending sediment particles, oxygen concentrations in the bottom water, the concentration and type of organic ligands actively stabilizing $\mathrm{dFe}$, or the presence of $\mathrm{dFe}$ scavenging particles settling to the bottom (de Jong et al., 2012; Klunder et al., 2011). Once dFe (in free inorganic or ligand-complexed form) leaves the bottom layer closer to the sediment-water interface, the combination of diffusion and vertical advection brings $\mathrm{dFe}$ to the surface where lateral transport distributes it in the region. Of the three mentioned processes, previous studies in the Southern Ocean (i.e. de Jong et al., 2012; Planquette et al., 2007) agree that lateral advection is the most important and efficient long-distance supplier of dFe (see also Lam et al., 2006).

Around South Georgia, the importance of lateral transport has been suggested by several authors (i.e. Korb et al., 2008) and is evident from our modelling results (Fig. 9a). Vertical upwelling during summer (as opposed to winter deep mixing) has also been highlighted as an important mechanism for bringing nutrients (macronutrients and iron) to the surface: for example, Brandon et al., 1999 described upwelling to the northeast of the island along a shelf-break front separating on-shelf and off-shelf waters, Whitehouse et al. (2008a) found evidence for upwelling to the southwest of the island where the easterly flowing ACC diverges as it meets the island, and more recently Nielsdóttir et al. (2012) pointed to eddy-driven mechanisms of vertical transport. Our sensitivity runs suggest that only a very small part of the total dFe measured at the surface derives from upwelling of deeper ironrich waters. However, as noted previously, the lack of tidal forcing and the coarse grid resolution $(11 \mathrm{~km})$ will not allow a full representation of vertical processes acting at the mesoand sub-mesoscale or in relation to the presence of eddies and tides better represented by higher-resolution models (Naveira Garabato et al., 2002; Young et al., 2011). Moreover, a more realistic bathymetry would improve the interaction between flow and bottom topography, which can also generate sites of local upwelling (Brandon et al., 1999). 
At the surface the main mechanisms removing $\mathrm{dFe}$ are likely to be biological uptake by phytoplankton and bacteria, scavenging onto sinking biogenic particles (i.e. dead phytoplankton cells), oxidation of dFe and its adsorption to colloids. However, the high surface $\mathrm{dFe}$ concentrations measured around South Georgia, which result from the combination of all processes mentioned above, clearly indicate that $\mathrm{dFe}$ sources are far more effective than $\mathrm{dFe}$ losses. In fact, Borrione and Schlitzer (2013) suggest that the termination of the first peak observed in South Georgia phytoplankton blooms does not strictly depend on $\mathrm{dFe}$ availability, but rather it may be caused by insufficient silicate levels, rapidly exhausted by the spring and early summer diatom blooms.

Iron-input mechanisms directly related to local hydrography, like lateral transport or tidal currents, are not expected to change significantly in time (i.e. at the seasonal or decadal scale), especially if they are steered by bottom topography (Borrione and Schlitzer, 2013). Conversely, iron-input mechanisms directly linked to weather or local climate (i.e. air temperature or precipitation) will likely follow a seasonal cycle, and possibly be modified in the future as a response to climate change. For example, during austral summer, dust emission from the Patagonian Desert and snow- and ice melt are at their maximum levels and hence coincide in timing with the main phytoplankton growing season (Johnson et al., 2010; Young et al., 2011; Borrione and Schlitzer, 2013): during this time of the year the growing and iron-demanding phytoplankton community can count on an additional exogenous source of iron other than the continuous supply of iron from sedimentary sources. An increase in dFe input can be expected at the longer timescales due to the gradual but progressive increase in ocean and air temperatures which are leading to increased glacier melt (Gordon et al., 2008; Whitehouse et al., 2008b). Previous studies investigating the magnitude of climate-change-induced dust emission and deposition from the world's deserts provide contrasting results, depending on the models and initial scenarios used (Mahowald and Luo, 2003; Tegen et al., 2004). However, considering the stronger effect of sedimentary versus atmospheric sources of iron to the main South Georgia bloom area revealed by the current study, we suggest that either an increase or decrease in future dust deposition will have a negligible effect on primary productivity (see also Tagliabue et al., 2008; Aumont et al., 2008).

\subsection{Model uncertainties}

Comparison of modelled surface $\mathrm{dFe}$ concentrations with recently published underway $\mathrm{dFe}$ concentrations measured around South Georgia (Figs. 7a and 8) reconfirm the ability of PISCES (here coupled to ROMS_AGRIF) to reproduce the main distribution features of surface $\mathrm{dFe}$, and, to an adequate level, also absolute dFe concentrations. Results shown in Fig. 6 indicate that patterns in simulated and observed surface $\mathrm{Chl} a$ concentrations have many similarities because in both data sets location and size of the blooms clearly depend on local circulation, which is also reproduced adequately by the model. However, observed and modelled Chl $a$ concentrations are significantly different in their absolute values: modelled $\mathrm{Chl} a$ concentrations are lower than those observed in January-February 2008, but also lower than the concentrations recorded during the less productive months of January-February 2011. Moreover, the bloom modelled to the north and northeast of South Georgia is further south than observed. Differences between the two data sets indicate that in the current configuration of PISCES applied to the region around South Georgia, certain biogeochemical processes may not be fully resolved.

The first important difficulty encountered in biogeochemical models applied to the iron-limited Southern Ocean is the correct representation of the complex iron cycle, necessarily simplified because of the large number of uncertainties and limited number of observations (Aumont and Bopp, 2006). Iron in seawater is present in various oxidation forms and it interacts with several types and size classes of suspended particles and ligands. In the current configuration of PISCES, iron is present in dissolved form and it is assumed to be all bioavailable (as in Moore and Braucher, 2008). In the model $\mathrm{dFe}$ may interact with biogenic particles only. Although recent investigations indicated the ubiquity of inorganic particulate iron, especially downstream of coastal regions (i.e. Lam et al., 2006), they also suggested its bioavailability (i.e. Raiswell et al., 2008). The inorganic form of particulate iron is currently not included in the model, as almost no quantitative information is available to parametrize this source $(\mathrm{Au}-$ mont and Bopp, 2006). Furthermore, recent studies show that the concentration of ligands, which are responsible for the stabilization and hence prolonged bioavailability of $\mathrm{dFe}$ in the water column, is very variable in space, time and depth; in particular, ligands are present at higher concentrations where productivity is high (Hunter and Boyd, 2007; Moore and Braucher, 2008), as would likely be the case over the South Georgia main bloom area. In the model, however, there is only one type of ligand, and it is present at constant concentrations throughout the whole water column. Consequently, an underestimate of the total concentration of bioavailable iron, which is potentially also present in the form of inorganic particulate iron, or complexed to higher concentrations of ligands, may result in the low modelled $\mathrm{Chl} a$ concentrations, or smaller-sized blooms. To date, there are no in situ measurements around South Georgia that could improve our understanding of the role of particulate iron in the region, including its bioavailability and transport scale lengths. Additional measurements are fundamental to confirm or reject our hypothesis, but will also improve the description of iron distributions farther away from the island (i.e. along the $\mathrm{Chl}$ $a$-rich plume extending due east of the Georgia Basin) where in situ data is not available. 
The lifetime of iron in the surface layer depends on the interaction between chemical, physical and biological processes removing or reintroducing iron. As mentioned above, the presence of ligands is crucial to keep iron dissolved in seawater (Hunter and Boyd, 2007), while diffusion, as well as lateral and vertical mixing or advection (Fig. 11) provides the means for iron supply from more enriched waters. Indeed, also the biological recycling of iron, due to phytoplankton, zooplankton and bacteria, will increase the lifetime of iron in the surface. Although these processes are represented in the model (Fig. 3), their relative importance may be affected by uncertainties in the rates of biological iron uptake, chemical processing, and its release into the water column (Baker and Croot, 2010).

\section{Conclusions}

Natural input of iron around South Georgia was investigated using the coupled physical-biogeochemical model ROMS_AGRIF-PISCES, implemented for the first time to a region of the Southern Ocean. The model captures the main features of circulation and chlorophyll biomass around the island, corroborating the island mass effect for South Georgia. In particular, the model can reproduce $\mathrm{dFe}$ distributions previously described with few discrete in situ measurements around South Georgia, and hence presents a large-scale, yet detailed view of iron distribution, scale lengths and principal transport pathways around the island. To date this information was absent, and can now offer a useful tool to biogeochemists investigating the occurrence of phytoplankton blooms in the region but can also provide a base line for future in situ investigations. Clearly, some important questions remain open. Although the model captures adequately the overall distribution and magnitude of $\mathrm{dFe}$ distribution in the region as well as the main spatial patterns of phytoplankton blooms, modelled $\mathrm{Chl} a$ concentrations are significantly lower than in observations. This evident discrepancy may suggest that the total amount of iron bioavailable to phytoplankton includes but is not limited to $\mathrm{dFe}$, and that recycling processes may be more efficient than currently simulated. Both aspects need to be verified by future investigations. In the meantime, as the model used in this study has proven its ability to simulate the South Georgia island mass effect in HNLC waters, additional model sensitivity tests could be performed in the future to estimate the levels of bioavailable iron necessary to stimulate the particularly intense annual phytoplankton blooms observed downstream of South Georgia.
Acknowledgements. J. Deshayes, T. Gorgues, Y. Jose, C. Klaas, E. Machu, M. Menzel, P. Penven, R. Timmermann, V. Smetacek and C. Völker are acknowledged for valuable discussions and help during the implementation of the models in a new study region. The Deutsches Klimarechenzentrum (DKRZ) hosting the model code is also thanked for its technical support. This work is part of Ph.D. research by I. Borrione, supported by the Earth System Science Research School at the Alfred Wegener Institute Helmholtz-Centre for Polar and Marine Research and the EU FP7 project CARBOCHANGE under grant agreement no. 264879. The $\mathrm{PhD}$ studentship grant to M. C. Nielsdóttir by the University of Southampton, the National Oceanography Centre, Southampton and by the Antarctic Funding Initiative under the Collaborative Gearing Scheme (CGS8/27 and CGS9/34) is also acknowledged. In particular, we acknowledge the late Gökay Karakaş, to whom this scientific contribution is dedicated.

Edited by: G. Herndl

\section{References}

Ardelan, M. V., Holm-Hansen, O., Hewes, C. D., Reiss, C. S., Silva, N. S., Dulaiova, H., Steinnes, E., and Sakshaug, E.: Natural iron enrichment around the Antarctic Peninsula in the Southern Ocean, Biogeosciences, 7, 11-25, doi:10.5194/bg-7-11-2010, 2010.

Assmy, P., Smetacek, V., Montresor, M., Klaas, C., Henjes, J., Strass, V. H., Arrieta, J. M., Bathmann, U., Berg, G. M., Breitbarth, E., Cisewski, B., Friedrichs, L., Fuchs, N., Herndl, G. J., Jansen, S., Krägefsky, S., Latasa, M., Peeken, I., Röttgers, R., Scharek, R., Schüller, S. E., Steigenberger, S., Webb, A., and Wolf-Gladrow, D.: Thick-shelled, grazer-protected diatoms decouple ocean carbon and silicon cycles in the ironlimited Antarctic Circumpolar Current, P. Natl. Acad. Sci., doi:10.1073/pnas.1309345110, 2013.

Aumont, O. and Bopp, L.: Globalizing results from ocean in situ iron fertilization studies, Global Biogeochem. Cy., 20, GB2017, doi:10.1029/2005GB002591, 2006.

Aumont, O., Maier-Reimer, E., Blain, S., and Monfray, P.: An ecosystem model of the global ocean including $\mathrm{Fe}$, $\mathrm{Si}$, P colimitations, Global Biogeochem. Cy., 17, 1060, doi:10.1029/2001GB001745, 2003.

Aumont, O., Bopp, L., and Schulz, M.: What does temporal variability in aeolian dust deposition contribute to sea-surface iron and chlorophyll distributions?, Geophys. Res. Lett., 35, L07607, doi:10.1029/2007gl031131, 2008.

Baker, A. R. and Croot, P. L.: Atmospheric and marine controls on aerosol iron solubility in seawater, Mar. Chem., 120, 4-13, doi:10.1016/j.marchem.2008.09.003, 2010.

Beckmann, A. and Haidvogel, D. B.: Numerical simulation of flow around a tall isolated seamount. Part I: Problem formulation and model accuracy, J. Phys. Oceanogr., 23, 1736-1753, doi:10.1175/1520-0485(1993)023<1736:NSOFAA>2.0.CO;2, 1993. 
Blain, S., Sarthou, G., and Laan, P.: Distribution of dissolved iron during the natural iron-fertilization experiment KEOPS (Kerguelen Plateau, Southern Ocean), Deep-Sea Res. Pt. II, 55, 594-605, doi:10.1016/j.dsr2.2007.12.028, 2008.

Borrione, I. and Schlitzer, R.: Distribution and recurrence of phytoplankton blooms around South Georgia, Southern Ocean, Biogeosciences, 10, 217-231, doi:10.5194/bg-10-217-2013, 2013.

Bouffard, J., Vignudelli, S., Cipollini, P., and Menard, Y.: Exploiting the potential of an improved multimission altimetric data set over the coastal ocean, Geophys. Res. Lett., 35, L10601, doi:10.1029/2008g1033488, 2008.

Brandon, M. A., Murphy, E. J., Whitehouse, M. J., Trathan, P. N., Murray, A. W. A., Bone, D. G., and Priddle, J.: The shelf break front to the east of the sub-Antarctic island of South Georgia, Cont. Shelf Res., 19, 799-819, 1999.

Brzezinski, M. A., Nelson, D. M., Franck, V. M., and Sigmon, D. E.: Silicon dynamics within an intense open-ocean diatom bloom in the pacific sector of the southern ocean, Deep Sea Res. Pt. II, 48, 3997-4018, doi:10.1016/S0967-0645(01)00078-9, 2001.

Bucciarelli, E., Blain, S., and Tréguer, P.: Iron and manganese in the wake of the Kerguelen Islands (Southern Ocean), Mar. Chem., 73, 21-36, doi:10.1016/S0304-4203(00)00070-0, 2001.

Campanelli, A., Massolo, S., Grilli, F., Marini, M., Paschini, E., Rivaro, P., Artegiani, A., and Jacobs, S. S.: Variability of nutrient and thermal structure in surface waters between new zealand and antarctica, October 2004-January 2005, Polar Res., 30, 2011.

Carton, J. A. and Giese, B. S.: A Reanalysis of Ocean Climate Using Simple Ocean Data Assimilation (SODA), Mon. Weather Rev., 136, 2999-3017, doi:10.1175/2007mwr1978.1, 2008.

Casey, K. S. and Cornillon, P.: A comparison of satellite and in situ-based sea surface temperature climatologies, J. Climate, 12, 1848-1863, doi:10.1175/15200442(1999)012<1848:acosai>2.0.co;2, 1999.

Chelton, D. B., deSzoeke, R. A., Schlax, M. G., El Naggar, K., and Siwertz, N.: Geographical Variability of the First Baroclinic Rossby Radius of Deformation, J. Phys. Oceanogr., 28, 433-460, doi:10.1175/1520-0485(1998)028<0433:gvotfb>2.0.co;2, 1998.

Chelton, D. B., Schlax, M. G., Freilich, M. H., and Milliff, R. F.: Satellite measurements reveal persistent smallscale features in ocean winds, Science, 303, 978-983, doi:10.1126/science.1091901, 2004.

Conkright, M. E., Locarnini, R. A., Garcia, H. E., O’Brien, T. D., Boyer, T. P., Stephens, C., and Antonov, J. I.: World Ocean Atlas 2001: Objective Analyses, Data Statistics, and Figures, CDROM Documentation, National Oceanographic Data Center, Silver Spring, MD, 17 pp., 2002.

Da Silva, A. M., Young, C. C., and Levitus, S.: Atlas of Surface Marine Data 1994, vol. 1, Algorithms and Procedures, NOAA Atlas NESDIS 6, US Department of Commerce, NOAA, NESDIS, USA, 74 pp., 1994.

Debreu, L. and Blayo, E.: Two-way embedding algorithms: a review, Ocean Dynam., 58, 415-428, doi:10.1007/s10236-0080150-9, 2008.

de Jong, J., Schoemann, V., Lannuzel, D., Croot, P., de Baar, H., and Tison, J.-L.: Natural iron fertilization of the Atlantic sector of the Southern Ocean by continental shelf sources of the Antarctic Peninsula, J. Geophys. Res., 117, G01029, doi:10.1029/2011jg001679, 2012.
Elrod, V. A., Berelson, W. M., Coale, K. H., and Johnson, K. S.: The flux of iron from continental shelf sediments: a missing source for global budgets, Geophys. Res. Lett., 31, L12307, doi:10.1029/2004g1020216, 2004.

Fretwell, P. T., Tate, A. J., Deen, T. J., and Belchier, M.: Compilation of a new bathymetric dataset of south georgia, Antarct. Sci., 21, 171-174, doi:10.1017/S0954102008001703, 2009.

Gargett, A., Wells, J., Tejada-Martínez, A. E., and Grosch, C. E.: Langmuir supercells: a mechanism for sediment resuspension and transport in shallow seas, Science, 306, 1925-1928, doi:10.1126/science.1100849, 2004.

Gassó, S. and Stein, A. F.: Does dust from patagonia reach the sub-antarctic atlantic ocean?, Geophys. Res. Lett., 34, L01801, doi:10.1029/2006g1027693, 2007.

Gerringa, L. J. A., Alderkamp, A.-C., Laan, P., Thuróczy, C.-E., De Baar, H. J. W., Mills, M. M., van Dijken, G. L., Haren, H. V., and Arrigo, K. R.: Iron from melting glaciers fuels the phytoplankton blooms in Amundsen Sea (Southern Ocean): Iron biogeochemistry, Deep Sea Res. Pt. II, 71-76, 16-31, doi:10.1016/j.dsr2.2012.03.007, 2012.

Ginoux, P., Chin, M., Tegen, I., Prospero, J. M., Holben, B., Dubovik, O., and Lin, S.-J.: Sources and distributions of dust aerosols simulated with the GOCART model, J. Geophys. Res.Atmos., 106, 20255-20273, doi:10.1029/2000jd000053, 2001.

Gordon, J. E., Haynes, V. M., and Hubbard, A.: Recent glacier changes and climate trends on South Georgia, Global Planet. Change, 60, 72-84, doi:10.1016/j.gloplacha.2006.07.037, 2008.

Heimburger, A., Losno, R., Triquet, S., Dulac, F., and Mahowald, N.: Direct measurements of atmospheric iron, cobalt, and aluminum-derived dust deposition at Kerguelen Islands, Global Biogeochem. Cy., 26, GB4016, doi:10.1029/2012gb004301, 2012.

Holeton, C., Nédélec, F., Sanders, R., Brown, L., Moore, C., Stevens, D., Heywood, K., Statham, P., and Lucas, C.: Physiological state of phytoplankton communities in the Southwest Atlantic sector of the Southern Ocean, as measured by fast repetition rate fluorometry, Polar Biol., 29, 44-52, doi:10.1007/s00300-005-0028-y, 2005.

Hunter, K. A. and Boyd, P. W.: Iron-binding ligands and their role in the ocean biogeochemistry of iron, Environ. Chem. 4, 221-232, doi:10.1071/EN07012, 2007.

Jickells, T. D. and Spokes, L. J.: The biogeochemistry of iron in seawater, edited by: D. R. Turner, K. H., Wiley, Chichester, UK, 85-121 pp., 2001.

Johnson, K. S., Gordon, R. M., and Coale, K. H.: What controls dissolved iron concentrations in the world ocean?, Mar. Chem., 57, 137-161, doi:10.1016/S0304-4203(97)00043-1, 1997.

Johnson, M. S., Meskhidze, N., Solmon, F., Gassó, S., Chuang, P. Y., Gaiero, D. M., Yantosca, R. M., Wu, S., Wang, Y., and Carouge, C.: Modeling dust and soluble iron deposition to the South Atlantic Ocean, J. Geophys. Res., 115, D15202, doi:10.1029/2009jd013311, 2010.

Jones, E. M., Bakker, D. C. E., Venables, H. J., and Watson, A. J.: Dynamic seasonal cycling of inorganic carbon downstream of South Georgia, Southern Ocean, Deep-Sea Res. Pt. II, 59-60, 25-35, doi:10.1016/j.dsr2.2011.08.001, 2012.

Karakas, G., Nowald, N., Blaas, M., Marchesiello, P., Frickenhaus, S., Schlitzer, R.: High-resolution modeling of sediment erosion and particle transport across the northwest African shelf, 
J. Geophys. Res., 111, C06025, doi:10.1029/2005jc003296, 2006.

Klunder, M. B., Laan, P., Middag, R., De Baar, H. J. W., and van Ooijen, J. C.: Dissolved iron in the Southern Ocean (Atlantic sector), Deep-Sea Res. Pt. II, 58, 2678-2694, doi:10.1016/j.dsr2.2010.10.042, 2011.

Korb, R. E. and Whitehouse, M.: Contrasting primary production regimes around South Georgia, Southern Ocean: large blooms versus high nutrient, low chlorophyll waters, Deep-Sea Res. Pt. I, 51, 721-738, doi:10.1016/j.dsr.2004.02.006, 2004.

Korb, R. E., Whitehouse, M. J., and Ward, P.: SeaWiFS in the southern ocean: spatial and temporal variability in phytoplankton biomass around South Georgia, Deep-Sea Res. Pt. II, 51, 99-116, doi: 10.1016/j.dsr2.2003.04.002, 2004.

Korb, R. E., Whitehouse, M. J., Atkinson, A., and Thorpe, S. E.: Magnitude and maintenance of the phytoplankton bloom at South Georgia: a naturally iron-replete environment, Mar. Ecol.Prog. Ser., 368, 75-91, doi:10.3354/meps07525, 2008.

Korb, R. E., Whitehouse, M. J., Ward, P., Gordon, M., Venables, H. J., and Poulton, A. J.: Regional and seasonal differences in microplankton biomass, productivity, and structure across the Scotia Sea: Implications for the export of biogenic carbon, Deep-Sea Res. Pt. II, 59-60, 67-77, doi:10.1016/j.dsr2.2011.06.006, 2012.

Lam, P. J., Bishop, J. K. B., Henning, C. C., Marcus, M. A., Waychunas, G. A., and Fung, I. Y.: Wintertime phytoplankton bloom in the subarctic Pacific supported by continental margin iron, Global Biogeochem. Cy., 20, GB1006, doi:10.1029/2005gb002557, 2006.

Lannuzel, D., Schoemann, V., de Jong, J., Tison, J.-L., and Chou, L.: Distribution and biogeochemical behaviour of iron in the east antarctic sea ice, Mar. Chem., 106, 18-32, doi:10.1016/j.marchem.2006.06.010, 2007.

Li, F., Ginoux, P., and Ramaswamy, V.: Distribution, transport, and deposition of mineral dust in the Southern Ocean and Antarctica: Contribution of major sources, J. Geophys. Res., 113, D10207, doi:10.1029/2007JD009190, 2008.

Li, F., Ginoux, P., and Ramaswamy, V.: Transport of patagonian dust to antarctica, J. Geophys. Res., 115, D18217, doi:10.1029/2009jd012356, 2010.

Mahowald, N. M., Baker, A. R., Bergametti, G., Brooks, N., Duce, R. A., Jickells, T. D., Kubilay, N., Prospero, J. M., and Tegen, I.: Atmospheric global dust cycle and iron inputs to the ocean, Global Biogeochem. Cy., 19, GB4025, doi: 10.1029/2004gb002402, 2005.

Mahowald, N. M. and Luo, C.: A less dusty future?, Geophys. Res. Lett., 30, 1903, doi:10.1029/2003g1017880, 2003.

Meredith, M. P., Brandon, M. A., Murphy, E. J., Trathan, P. N., Thorpe, S. E., Bone, D. G., Chernyshkov, P. P., and Sushin, V. A.: Variability in hydrographic conditions to the east and northwest of south georgia, 1996-2001, J. Mar. Syst., 53, 143-167, doi:10.1016/j.jmarsys.2004.05.005, 2005.

Meredith, M. P., Watkins, J. L., Murphy, E. J., Cunningham, N. J., Wood, A. G., Korb, R., Whitehouse, M. J., Thorpe, S. E., and Vivier, F.: An anticyclonic circulation above the Northwest Georgia Rise, Southern Ocean, Geophys. Res. Lett., 30, 2061, doi:10.1029/2003g1018039, 2003.

Meskhidze, N., Nenes, A., Chameides, W. L., Luo, C., and Mahowald, N.: Atlantic Southern Ocean productivity: Fertilization from above or below?, Global Biogeochem. Cy, 21, GB2006, doi: 10.1029/2006gb002711, 2007.

Middelburg, J. J., Soetaert, K., Herman, P. M. J., and Heip, C. H. R.: Denitrification in marine sediments: A model study, Global Biogeochem. Cy., 10, 661-673, doi:10.1029/96gb02562, 1996.

Moore, J. K., Abbott, M. R., and Richman, J. G.: Location and dynamics of the Antarctic Polar Front from satellite sea surface temperature data, J. Geophys. Res., 104, 3059-3073, doi:10.1029/1998jc900032, 1999.

Moore, J. K. and Braucher, O.: Sedimentary and mineral dust sources of dissolved iron to the world ocean, Biogeosciences, 5, 631-656, doi:10.5194/bg-5-631-2008, 2008.

Naveira Garabato, A. C., Strass, V. H., and Kattner, G.: Fluxes of nutrients in a three-dimensional meander structure of the Antarctic Polar Front, Deep-Sea Res. Pt. II, 49, 3771-3792, doi:10.1016/S0967-0645(02)00110-8, 2002.

Nielsdóttir, M. C., Bibby, T. S., Moore, C. M., Hinz, D. J., Sanders, R., Whitehouse, M., Korb, R., and Achterberg, E. P.: Seasonal and spatial dynamics of iron availability in the Scotia Sea, Mar. Chem., 130-131, 62-72, doi:10.1016/j.marchem.2011.12.004, 2012.

Orsi, A. H., Whitworth, T., and Nowlin, W. D.: On the meridional extent and fronts of the Antarctic Circumpolar Current, DeepSea Res. Pt. I, 42, 641-673, doi:10.1016/0967-0637(95)00021W, 1995.

Parekh, P., Follows, M. J., and Boyle, E.: Modeling the global ocean iron cycle, Global Biogeochem. Cy., 18, GB1002, doi:10.1029/2003GB002061, 2004.

Penven, P., Debreu, L., Marchesiello, P., and McWilliams, J. C.: Evaluation and application of the ROMS 1-way embedding procedure to the central california upwelling system, Ocean Model., 12, 157-187, doi:10.1016/j.ocemod.2005.05.002, 2006.

Penven, P., Marchesiello, P., Debreu, L., and Lefèvre, J.: Software tools for pre- and post-processing of oceanic regional simulations, Environ. Modell. Softw., 23, 660-662, doi:10.1016/j.envsoft.2007.07.004, 2008.

Planquette, H., Statham, P. J., Fones, G. R., Charette, M. A., Moore, C. M., Salter, I., Nédélec, F. H., Taylor, S. L., French, M., Baker, A. R., Mahowald, N., and Jickells, T. D.: Dissolved iron in the vicinity of the Crozet Islands, Southern Ocean, DeepSea Res. Pt. II, 54, 1999-2019, doi:10.1016/j.dsr2.2007.06.019, 2007.

Raiswell, R., Benning, L. G., Davidson, L., and Tranter, M.: Nanoparticulate bioavailable iron minerals in icebergs and glaciers, Mineral. Mag., 72, 345348,doi:10.1180/minmag.2008.072.1.345, 2008.

Shchepetkin, A. F. and McWilliams, J. C.: The regional oceanic modeling system (ROMS): a split-explicit, free-surface, topography-following-coordinate oceanic model, Ocean Model., 9, 347-404, doi:10.1016/j.ocemod.2004.08.002, 2005.

Ridgway, K. R., Dunn, J. R., and Wilkin, J. L.: Ocean interpolation by four-dimensional least squares-application to the waters around Australia, J. Atmos. Ocean. Tech., 19, 1357-1375, 2002.

Slemons, L., Gorgues, T., Aumont, O., Menkes, C., and Murray, J. W.: Biogeochemical impact of a model western iron source in the Pacific Equatorial Undercurrent, Deep-Sea Res. Pt. I, 56, 2115-2128, doi:10.1016/j.dsr.2009.08.005, 2009. 
Smith, W. H. F. and Sandwell, D. T.: Global sea floor topography from satellite altimetry and ship depth soundings, Science, 277, 1956-1962, doi:10.1126/science.277.5334.1956, 1997.

Tagliabue, A., Bopp, L., and Aumont, O.: Ocean biogeochemistry exhibits contrasting responses to a large scale reduction in dust deposition, Biogeosciences, 5, 11-24, doi:10.5194/bg-5-112008, 2008 .

Tagliabue, A., Bopp, L., and Aumont, O.: Evaluating the importance of atmospheric and sedimentary iron sources to Southern Ocean biogeochemistry, Geophys. Res. Lett., 36, L13601, doi:10.1029/2009gl038914, 2009.

Taylor, M. H., Losch, M., and Bracher, A.: On the drivers of phytoplankton blooms in the antarctic marginal ice zone: A modeling approach, J. Geophys. Res. Ocean, n/a-n/a, doi:10.1029/2012jc008418, 2013.

Tegen, I. and Fung, I.: Contribution to the atmospheric mineral aerosol load from land surface modification, J. Geophys. Res.Atmos., 100, 18707-18726, doi:10.1029/95jd02051, 1995.

Tegen, I., Werner, M., Harrison, S. P., and Kohfeld, K. E.: Relative importance of climate and land use in determining present and future global soil dust emission, Geophys. Res. Lett., 31, L05105, doi:10.1029/2003g1019216, 2004.

Thorpe, S. E., Heywood, K. J., Brandon, M. A., and Stevens, D. P.: Variability of the southern Antarctic Circumpolar Current front north of South Georgia, J. Marine Syst., 37, 87-105, doi:10.1016/S0924-7963(02)00197-5, 2002.

Tovar-Sanchez, A., Duarte, C. M., Hernández-León, S., and Sañudo-Wilhelmy, S. A.: Krill as a central node for iron cycling in the southern ocean, Geophys. Res. Lett., 34, L11601, doi:10.1029/2006g1029096, 2007.

Venables, H., Meredith, M. P., Atkinson, A., and Ward, P.: Fronts and habitat zones in the Scotia Sea, Deep-Sea Res. Pt. II, 59-60, 14-24, doi:10.1016/j.dsr2.2011.08.012, 2012.

Volkov, D. L., Larnicol, G., and Dorandeu, J.: Improving the quality of satellite altimetry data over continental shelves, J. Geophy. Res. Ocean, 112, C06020, doi:10.1029/2006jc003765, 2007.
Ward, P., Shreeve, R., Whitehouse, M., Korb, B., Atkinson, A., Meredith, M., Pond, D., Watkins, J., Goss, C., and Cunningham, N.: Phyto- and zooplankton community structure and production around South Georgia (Southern Ocean) during Summer 2001/02, Deep-Sea Res. Pt. I, 52, 421-441, doi:10.1016/j.dsr.2004.10.003, 2005.

Whitehouse, M. J., Priddle, J., and Brandon, M. A.: Chlorophyll/nutrient characteristics in the water masses to the north of South Georgia, Southern Ocean Polar Biology, 23, 373-382, doi:10.1007/s003000050458, 2000.

Whitehouse, M. J., Priddle, J., and Symon, C.: Seasonal and annual change in seawater temperature, salinity, nutrient and chlorophyll $a$ distributions around South Georgia, South Atlantic, Deep-Sea Res. Pt. I, 43, 425-443, doi:10.1016/09670637(96)00020-9, 1996.

Whitehouse, M. J., Korb, R. E., Atkinson, A., Thorpe, S. E., and Gordon, M.: Formation, transport and decay of an intense phytoplankton bloom within the high-nutrient low-chlorophyl belt of the Southern Ocean, J. Marine Syst., 70, 150-167, doi:10.1016/j.jmarsys.2007.05.003, 2008a.

Whitehouse, M. J., Meredith, M. P., Rothery, P., Atkinson, A., Ward, P., and Korb, R. E.: Rapid warming of the ocean around South Georgia, Southern Ocean, during the 20th century: forcings, characteristics and implications for lower trophic levels, Deep-Sea Res. Pt. I, 55, 1218-1228, doi:10.1016/j.dsr.2008.06.002, 2008 b.

Whitehouse, M. J., Atkinson, A., Ward, P., Korb, R. E., Rothery, P., and Fielding, S.: Role of krill versus bottom-up factors in controlling phytoplankton biomass in the northern antarctic waters of south georgia, Mar. Ecol.-Prog. Ser., 393, 69-82, doi:10.3354/meps08288, 2009.

Young, E. F., Meredith, M. P., Murphy, E. J., and Carvalho, G. R.: High-resolution modelling of the shelf and open ocean adjacent to South Georgia, Southern Ocean, Deep-Sea Res. Pt. II, 58, 1540-1552, doi:10.1016/j.dsr2.2009.11.003, 2011. 